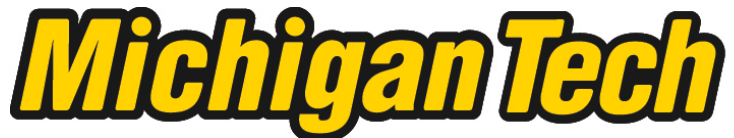 \\ Michigan Technological University Create the Future Digital Commons @ Michigan Tech
}

\section{An ethnobotanical survey of the economic and cultural significance of non-timber forest products in the southwest Rhodope Mountain region of Bulgaria}

Callie A. Bertsch

Michigan Technological University

Follow this and additional works at: https://digitalcommons.mtu.edu/etds

Part of the Forest Sciences Commons

Copyright 2011 Callie A. Bertsch

Recommended Citation

Bertsch, Callie A., "An ethnobotanical survey of the economic and cultural significance of non-timber forest products in the southwest Rhodope Mountain region of Bulgaria", Master's Thesis, Michigan Technological University, 2011.

https://doi.org/10.37099/mtu.dc.etds/146

Follow this and additional works at: https://digitalcommons.mtu.edu/etds

8 Part of the Forest Sciences Commons 
AN ETHNOBOTANICAL SURVEY OF THE ECONOMIC AND CULTURAL SIGNIFICANCE OF NON-TIMBER FOREST PRODUCTS IN THE SOUTHWEST RHODOPE MOUNTAIN REGION OF BULGARIA

\author{
By \\ Callie A. Bertsch \\ A THESIS \\ Submitted in partial fulfillment of the requirements for the degree of \\ MASTER OF SCIENCE \\ Forestry
}

MICHIGAN TECHNOLOGICAL UNIVERSITY

2011

(C)2011 Callie A. Bertsch 
This thesis, "An Ethnobotanical Survey of the Economic and Cultural Significance of Non-Timber Forest Products in the Southwest Rhodope Mountain Region of Bulgaria," is hereby approved in partial fulfillment of the requirements for the Degree of MASTER OF SCIENCE IN FORESTRY.

School of Forest Resources and Environmental Science

Signatures:

Thesis Advisor

Dr. Blair D. Orr

Dean

Dr. Margaret R. Gale

Date 


\section{Table of Contents}

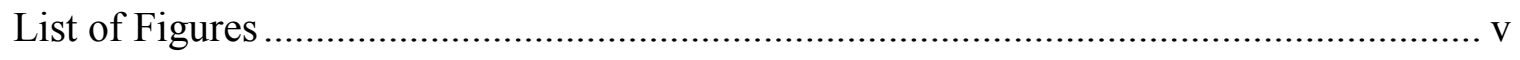

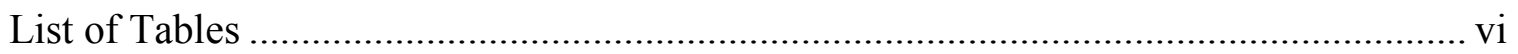

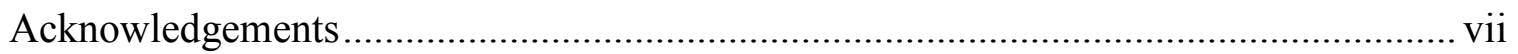

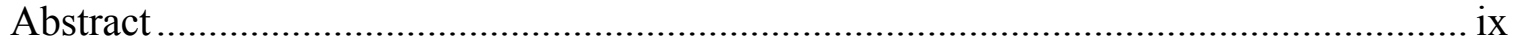

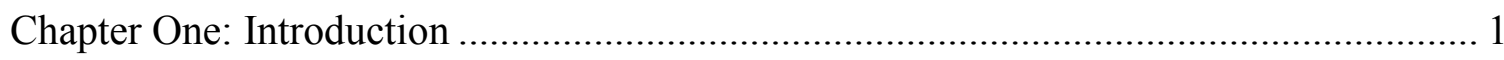

Chapter Two: Background

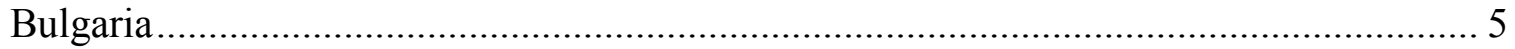

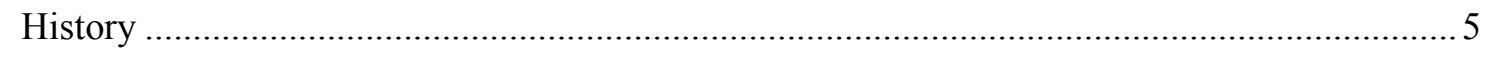

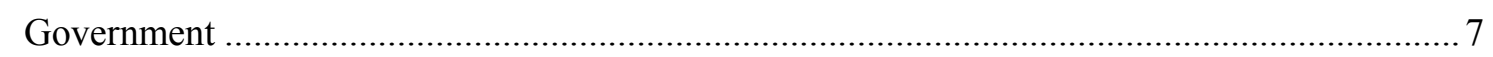

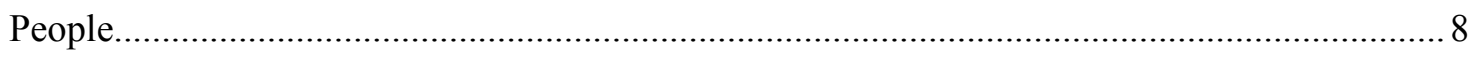

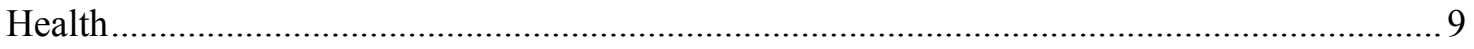

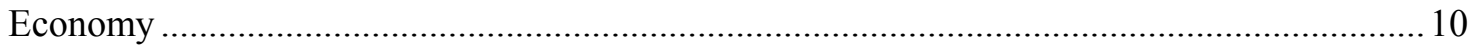

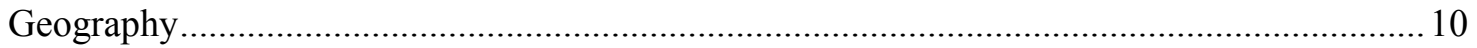

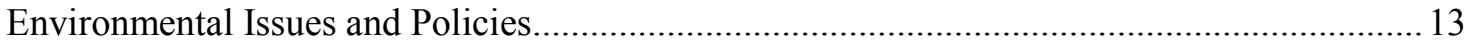

Chapter Three: Study Area Background

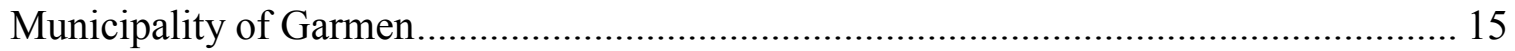

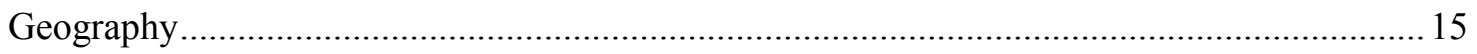

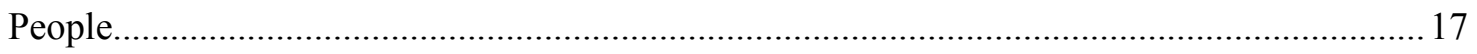

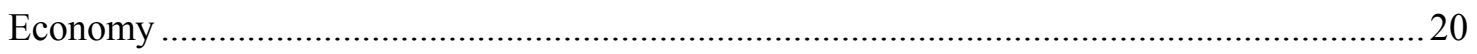

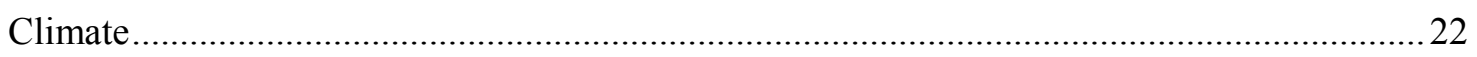

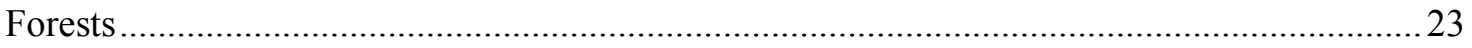

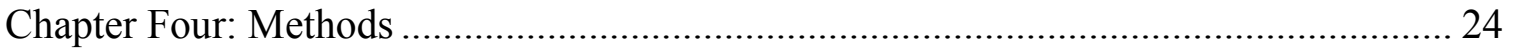

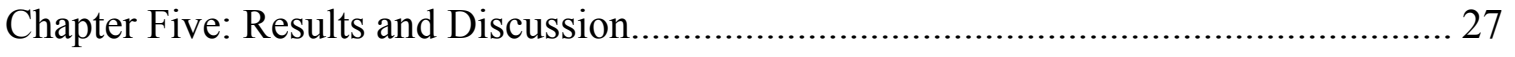

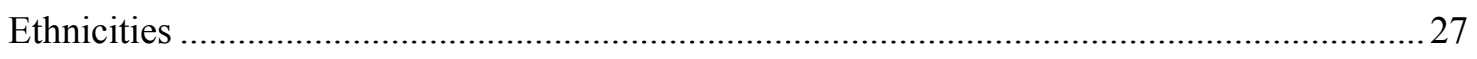

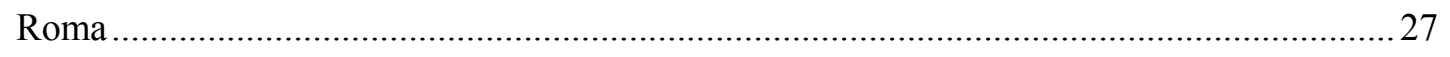

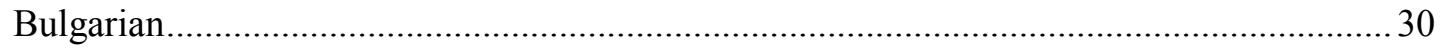

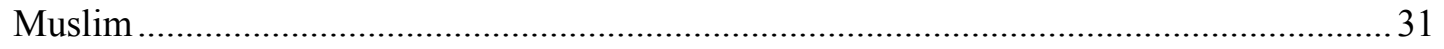

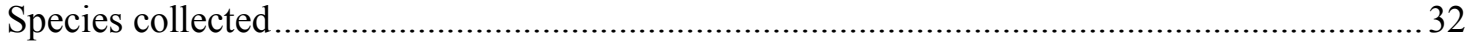

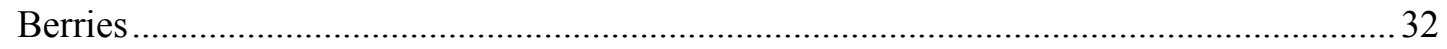

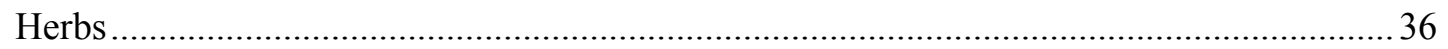




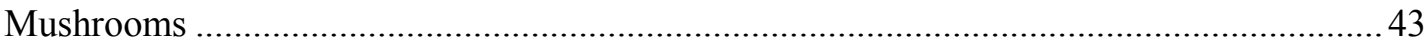

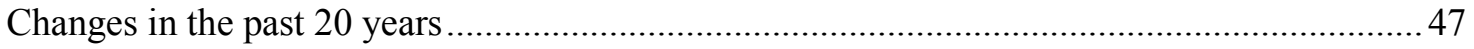

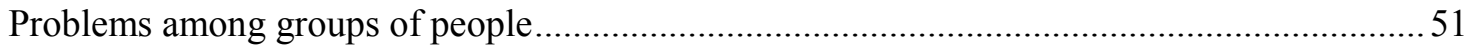

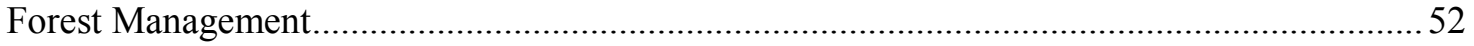

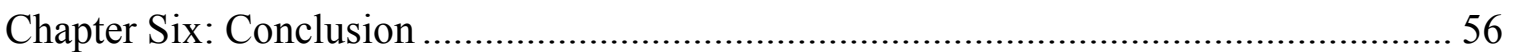

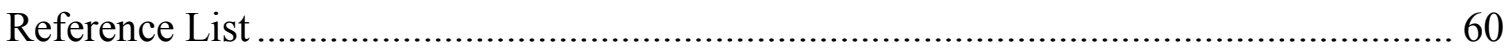

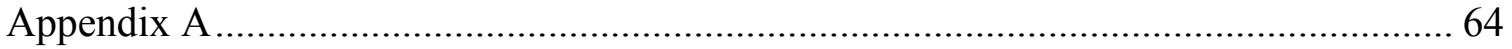

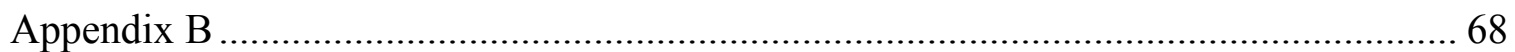




\section{List of Figures}

Figure 2.1: Ancient Thracian and Roman ruins 'Nikopolus ad Nestum' ......................... 7

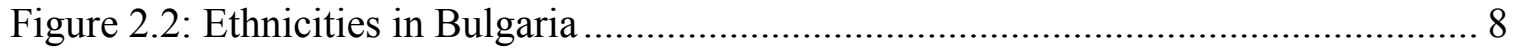

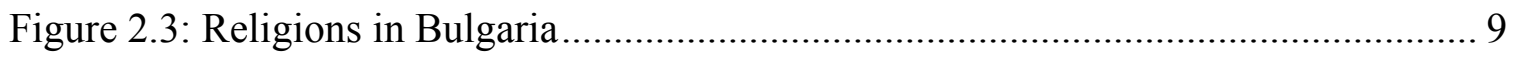

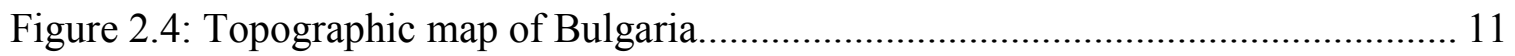

Figure 2.5: Seven Rila Lakes in the Rila Mountains, Bulgaria ..................................... 12

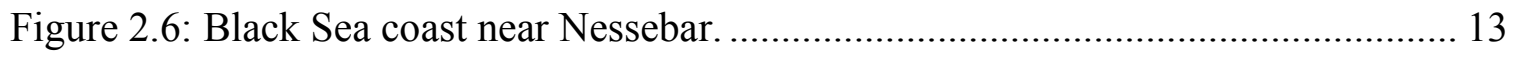

Figure 3.1: River Kanina Gorge, Municipality of Garmen ............................................. 15

Figure 3.2: Stone head at ancient Thracian worship site in Garmen ............................ 16

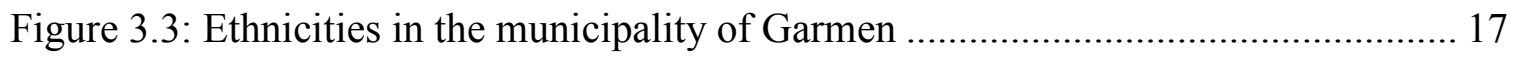

Figure 3.4: Age demographic in Municipality of Garmen. .......................................... 19

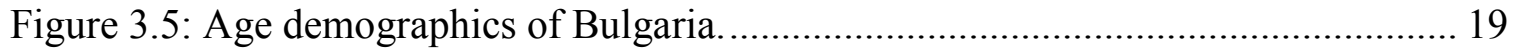

Figure 3.6: Number of Residents in Garmen employed in the industry sectors .............. 20

Figure 3.7: Number of Residents in Garmen employed in non-industry sectors............. 21

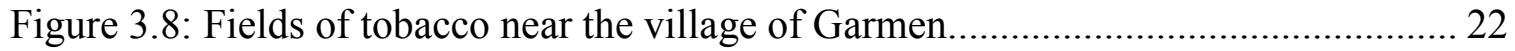

Figure 5.1: Roma woman selling mushrooms to a Bulgarian.................................... 29

Figure 5.2: Muslim woman collecting herbs while on a picnic .................................. 31

Figure 5.3: Muslim woman sorting through bilberries to make a compote..................... 33

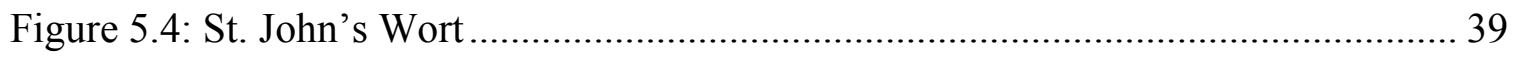

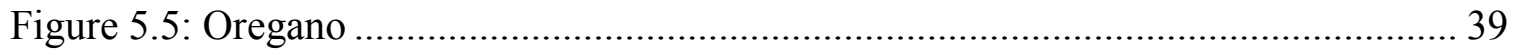

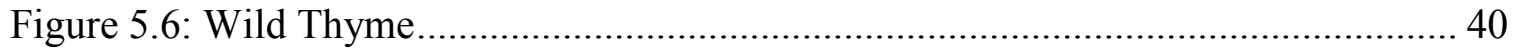

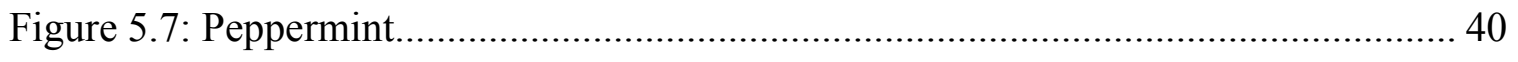

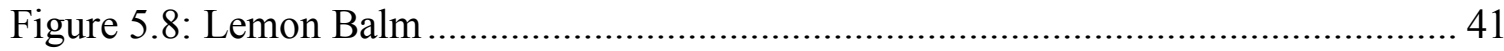

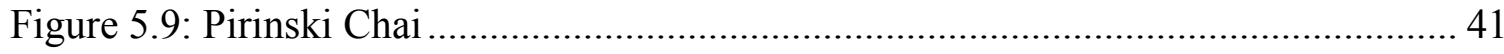

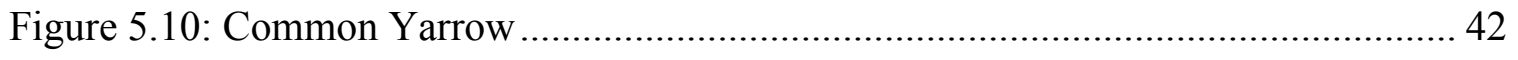

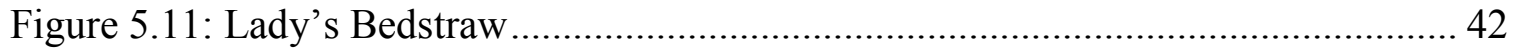

Figure 5.12: Manatarka at the buying station in Rakitovo........................................... 44

Figure 5.13: Patchikrak at the buying station in Rakitovo........................................ 44 


\section{List of Tables}

Table 5.1: Berry species collected including their purpose, method of preservation, and

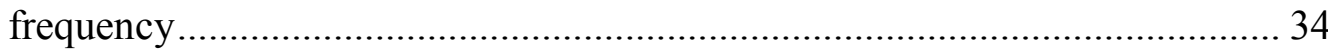

Table 5.2: Berry species collected including habitats and growth season........................ 35

Table 5.3: Herb species collected and their frequency ..................................................... 37

Table 5.4: Herb species collected and their habitats and growth season........................... 38

Table 5.5: Mushroom species collected and frequency ..................................................... 45

Table 5.6: Mushroom species collected including habitats and growing seasons........... 46 


\section{Acknowledgements}

This thesis was made possible foremost with the help from my advisor Dr. Blair Orr, whose insights, encouragement, advice, discernment, and humor helped make my Peace Corps, research, and thesis writing experiences enjoyable. I would also like to show my gratitude for my committee and their willingness to read my thesis and give critiques and comments in order to make it a better paper. Thank you to Dr. Rod Chimner, Dr. David Flaspohler, and Dr. Ron Gratz.

My family must be thanked for their patience and love while I lived away from home. To my parents: Andy and Cynthia, for loving me and allowing me to create and experience my dreams. For my brother who first introduced our family to the wonders of the Keweenaw Peninsula and to my sister and her husband who encouraged me to apply to the Master's International Program at Michigan Tech, and who gave me a beautiful little reason to come home half-way through my service -Ainslie-your smiling face encouraged me each step of the way!

To all the B24's, your love and support was an encouragement, as a group your abilities and potential awe me. Thank you for being my family and sharing in the Peace Corps adventure with me. Thank you to the other volunteers in Bulgaria who lived in the southwest Rhodope Mountain region and helped me in the research process, I loved having you along for the ride! To my friends and family from home who faithfully sent letters and packages to Bulgaria - it meant more to me than you will ever know!

Most importantly, and with many happy tears, I must thank the participants of this study who allowed me to interview them, but more importantly did it with pride of who they are and their culture. While I wish I could name every person who impacted my life while in Bulgaria, I must group them together and first thank the people associated with the Municipality of Garmen for allowing me to work in your building for two years, but more importantly for accepting me into your hearts and lives. I still miss your laughter and the dancing!!

To my dear friends in Bulgaria: Vaska, your listening ear and willingness to do anything for me can never be repaid, your kindness was beyond measure and I'm forever grateful and blessed to have you as a friend. To Vili, my counterpart, our repertoire of 
conversation is unending, your support either personally or work related went above and beyond. I will forever miss coffee after work or on Saturday mornings and our seaside adventures. To Boika and Ani and your families: thank you for accepting me into your homes unconditionally and introducing me to your culture. Lastly, to the community of Garmen, thank you for your hospitality and acceptance. 


\begin{abstract}
The people of the southwestern Rhodope Mountains of Bulgaria live in small, mountainous villages and rural areas. They rely on berries, herbs, and mushrooms provided by the forest and maintain a lifestyle and culture of gathering them. This study determined the economic and landscape concentration of Non-Timber Forest Products (NTFPs) and how this has changed in the past twenty years in the region of Garmen. The objective was to gauge the cultural and economic significance of NTFPs in the lives of the people who live there. Data was collected using informal, open-ended interviews and through participant observation. Results indicate that ethnicity influence how resources are utilized. Roma people collect mushrooms for income generation; Orthodox Bulgarians gather herbs, berries, and mushrooms for medicinal purposes, to supplement their diets, and to carry on traditions. Bulgarian Muslims collect for a combination of the aforementioned reasons. Changes that occur in the forests affect each of the ethnic groups in different ways and forest management practices should include people's knowledge and uses of NTFPs.
\end{abstract}




\section{Chapter One: Introduction}

It has been said that a man can never truly love his home until he leaves it. Those who have lived in countries other than their own may understand this on levels that pass from cultural relativism to ethnocentrism. Then you leave the country you have become so absorbed in that you experience the same thoughts, ideas, and emotions in reverse. And you find yourself truly loving both homes that you've once left.

The home I left in Bulgaria was surrounded by subsistence, the need to use available resources to survive not only physically, but as a culture. When I left the United States in 2008 to be a Community and Organizational Development Peace Corps Volunteer for two years in Bulgaria, many people commented that I was going to save the world. Sheepishly, I indicated that wasn't likely to happen, my mindset of helping people is an underlying theme and extends to every person I meet. My main goal was a personal challenge to live, work, breathe, and learn the language and culture of this foreign place.

Some days were frustrating. A trip to the capital city nearly always left me in tears as I couldn't seem to find kindness, but instead, outright animosity. My saving grace was the four hour bus rides first through the Rila Mountains, passing along the eastern edge of the Pirin Mountains, and finally finding myself home on the southwestern edge of the Rhodope Mountains, near the Greek border. It was here I found solace in the friendships, generosity, culture of the people, and beauty of the land.

My first experience with the people and their ties to the land was when a traditional Bulgarian family invited me on a picnic to collect shisharki (pinecones) so that they could make honey. It was a warm spring Saturday and we had been drinking coffee at the local café on the square when they invited me to join them. We spent a day lying on blankets, sunbathing, enjoying the three generations of the family present, eating cirene (cheese), tomatoes, and bread, and roaming the mountain side from tree to tree, trying to collect as many shisharki as we could. This was how they relaxed and enjoyed each other. I had reached rai (heaven).

Late one summer, I was helping with a weeklong summer camp for Roma children. One day we emphasized the environment and took the children on a hike into 
the hills. Immediately, the young boys were romping through the forests and emerged with enormous mushrooms. Their facial expressions and exclamations indicated the importance. "Look at this manatarka!! My mom is going to be so proud, it'll be worth so much money," exclaimed one boy. The other children looked in amazement; they knew how important the mushrooms were to each of their families as it was a viable means of earning income for this marginalized minority in Bulgaria.

Once, just before I was to come home to the United States to see my new niece, I became sick with a head cold. One of my closest friends in the village told me they couldn't send me home ill and brought me to her house. She pulled out her supply of herbs that she had collected in the forest and put them into a pot of boiling water, explaining which herb was which and how it would help me. I sat over the steaming pot for what seemed like hours, inhaling the scent of each of the herbs until I could breathe clearly. I then drank a tea with these herbs and a little rakia, a strong, homemade alcohol, and rubbed the rakia over my face. Whether it was the alcohol or the herbs, the next day I was well and ready to travel.

My most comforting experiences were with a Muslim coworker. Every morning he would bring me a steaming cup of over-sweetened hot tea that he had made with herbs he had collected from the forest exclaiming, "Here you go pilense (small chicken), ekologichni chisti (ecologically clean)!!" Then, he would explain how the herbs collected from the forest had the best aroma and no added chemicals; it was the only way to drink your tea. He once gave me a bouquet of oregano for tea and explained how this was a sign of friendship, to gift someone with something you had collected from the forest. It wasn't the last bouquet of herbs I would receive. They left me humbled and honored each time.

I knew that the non-timber forest products (NTFPs) found in Bulgaria were of cultural, medicinal, and economic importance for all of the ethnicities living there. I wanted to learn to what extent they were important to each person, if this had changed in the past 20 years as many other things had changed in Bulgaria since the end of communism, and to what extent forest management practices had on the availability of NTFPs. I wasn't saving the world, but I wanted to help preserve this part of their life. This was the basis and formation of this study. 
Furthermore, I have chosen to look at the broader topic of native people who are tied to their land and the importance of their knowledge when considering land management practices. Traditional ecological knowledge (TEK) is the "culturally and spiritually based way in which indigenous people relate to their ecosystems" (LaDuke 1994). It argues that the knowledge is based on observations and experiences from people and cultures that have been living in the same place for generations.

The use of TEK has been beneficial in the management and monitoring of changes in ecosystems where climate change has impacted the environment and people living in them (Zimmerman 2005). The participants interviewed for this study, those who collect NTFPs in rural Bulgaria, have a bond of knowing the land and its benefits. This knowledge can be instrumental in managing the land for protection of biodiversity and for sustainable resource use to help protect both the forests and the livelihood of the people (Berkes et al. 2000). The purpose of this study is to present the knowledge of the people of the southwest Rhodope Mountain region and describe how it can be utilized. I hypothesized that management of the forests that benefits all people was imperative to maintain the livelihoods of the people living there. I also hypothesized my results would be consistent with other studies that indicate cultural and economic values of NTFPs are fundamental aspects of life for local citizens.

Chapter two of this paper will present a general description of Bulgaria including its location, economic and government status, a brief history, and description of the people living there.

Chapter three will describe the study area, the Municipality of Garmen located in the southwestern Rhodope Mountains of southwestern Bulgaria. The geography, climate, economy, ethnic groups, and forest ecosystems will help to set a basis of knowledge for the people, ecosystem, and cultures studied.

Chapter four will outline the methods of this study. Chapter five presents the results and provides a discussion of the ethnobotanical research that was carried out over the summer of 2010. This chapter will encompass the five main topics that were delineated through participant observations and informal interviews conducted with the participants. 
Chapter six concludes with a return to the idea of traditional ecological knowledge and how it may help to protect the culture and economic importance of NTFPs through forest management. It also compares the similarities and differences between this study and others regarding the uses of NTFPs. 


\section{Chapter Two: Background Bulgaria}

Bulgaria is a nation that finds itself in continuous transition. Since the arrival of the Bulgar tribe of Turkic origins in the Balkan Peninsula leading to the formation of a state in $680 \mathrm{AD}$, the people have fought to maintain control of the land, government and, most recently, economy. Since the 1300s, Bulgaria has seen 500 years of Turkish Yoke under the Ottoman Empire followed by 45 years of Communist rule. The result is a people who are proud of their country and the difficulties they have overcome, yet sensitive to their weaknesses as they strive to be a viable member of the European Union (Crampton 2005).

In the words of a Bulgarian:

"Just look back. We have always been in some mess, either under

Ottoman control, clients of the Germans, part of the communist camp, and now in transition. And what is this transition? During my whole life we have been in some kind of transition: the transition to socialism, the transition to communism, and now the transition to capitalism. We are always in transition. The goals change, but we stay in transition. This is our fate, to always be on the road to somewhere we never reach. In my opinion we never even achieved socialism, not to speak of communism. Do you think we will do any better with capitalism or democracy? I doubt it, I really doubt it (Creed 1998)."

\section{History}

Before the establishment of the Turkic Bulgar tribe in the region, the area of Bulgaria was settled by Thracian tribes at the end of the third millennium BC, Romans in the third century BC, and Slavic tribes in the seventh century AD. During these periods, outside pressures from the Persians, Greek culture, and Alexander the Great influenced the politics and unity of the settlers. Remnants of these cultures are still found in 
Bulgaria and evidence the great history of a rather small and unknown country (Puncheva and Panova 2002).

Modern Bulgaria and its people are marred by the rule of the Ottomans from the late $14^{\text {th }}$ through the late $19^{\text {th }}$ century. A Bulgarian will tell you of the terrorism, turmoil, and constant persecution that ensued during these 500 years. However, other than the conflict between the Christians and Muslims, these years were peaceful but marked by occasions of gruesome acts of terrible outrage followed by rebellion. With help from the Russian army, Bulgaria was liberated from Ottoman rule in 1877 (Crampton 2005).

The time period between the end of Turkish rule and communism was characterized by political and social instability as well as participation in the first and second Balkan wars in 1912 and 1913. From 1944 to 1989, Bulgaria was a communist nation (U.S. State Department 2010). Many of the older generations in Bulgaria remember this time period as one of economic security and being treated well as Russia's little brother.

The years since communism have seen a lack of stability. On January 1, 2007, Bulgaria joined the European Union (EU). To many people this signified a chance for economic and political stability, but corruption in the government has prevented the country from receiving EU funding (U.S. State Department 2010). Bulgaria is one of the poorest and most corrupt of all the EU member countries. It ranks at 3.6 out of 10 on the corruption perceptions index in comparison with the United States which ranks 7.1 and Finland and Sweden which have the highest ranking at 9.2 (Transparency International 2010). 


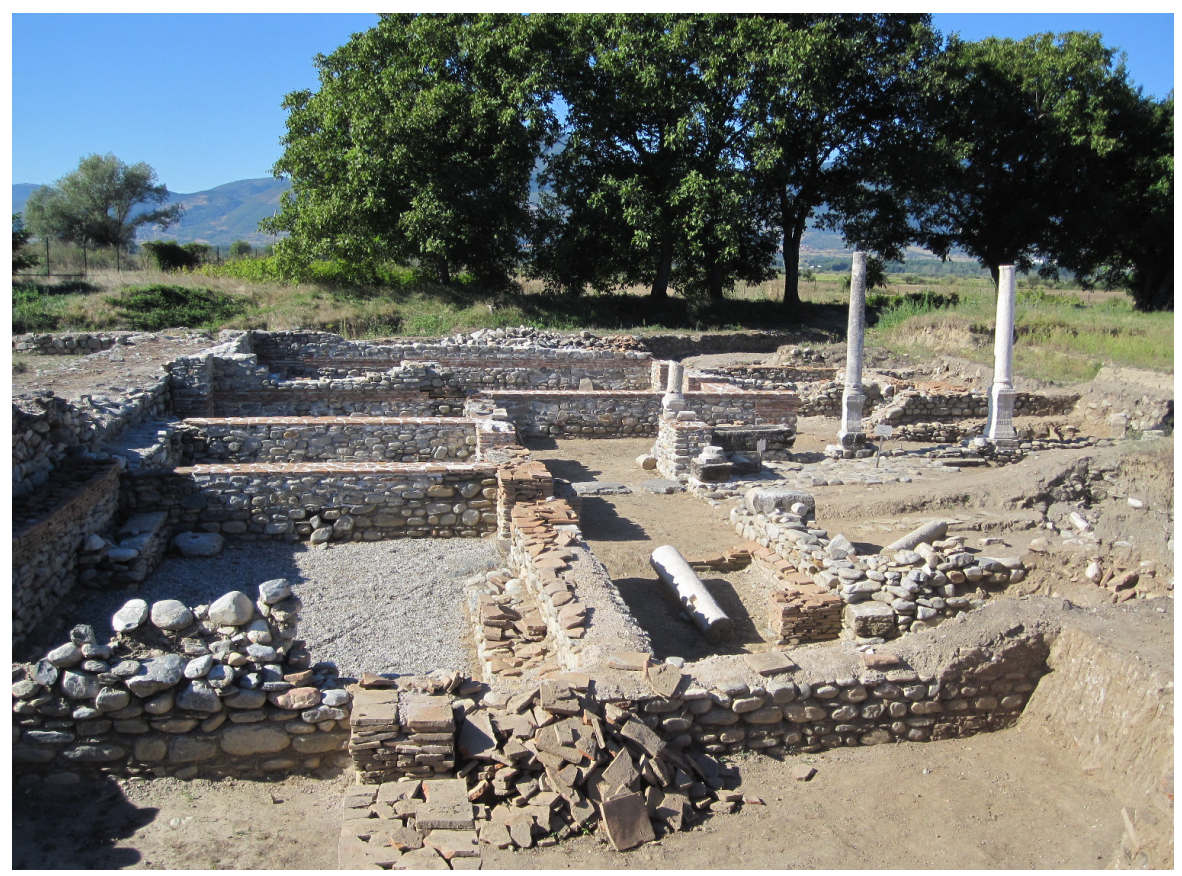

Figure 2.1: Ancient Thracian and Roman ruins 'Nikopolus ad Nestum' or City of Victory near the River Mesta. Photo: Katie Leu (see Appendix A)

\section{Government}

Bulgaria is a parliamentary democracy. Its constitution was adopted on July 12, 1991. The government consists of a president, prime minister, and a cabinet of ministers. The cabinet consists of 240 deputies who are elected for four year terms. Currently, there are six political parties that hold seats in parliament; however, there are over 17 political parties in Bulgaria (U.S. State Department 2010).

Parties must win with four percent of the vote in order to enter parliament, which is responsible for approval of the budget, enacting laws, declaration of war, scheduling presidential elections, and the ratification of international laws and treaties. It also selects and dismisses government officials, exercises control over government, and sanctions deployment of troops (U.S. State Department 2010).

The president is elected for a five-year term and may be re-elected once. He is the head of state and commander-in-chief of armed forces. The current president, Georgi Parvanov, is serving his second term after being initially elected in 2001 . He was elected 
as a member of the Bulgarian Socialist Party and reelected as an Independent (U.S. State Department 2010).

The prime minister leads the council of Ministers which is in charge of the various governmental agencies. Its main responsibilities include carrying out state policy, managing the budget, and maintaining law and order. The current Prime Minister, Boiko Borisov, was elected in 2009 as a member of the newly formed Citizens for the European Development of Bulgaria (GERB) political party. He is considered a people's man, coming from humble beginnings with little political experience. He is the former mayor of the capital city of Sofia and notoriously worked as a bodyguard for the former political leader, Todor Jivkov, during communism.

\section{People}

Bulgaria has a population of 7.6 million people. Ethnically, the majority of people are Bulgarians, with minorities of Turks and Roma (Figure 2.2). Two percent are of Macedonian, Armenian and other descents. Consequently, the main languages spoken in Bulgaria are Bulgarian, Turkish, and Romani. The official religion is Bulgarian Orthodox; however, all religious groups have freedom. The remaining religions include Islam, Roman Catholic and Protestant, and other groups (Figure 2.3) (CIA 2011).

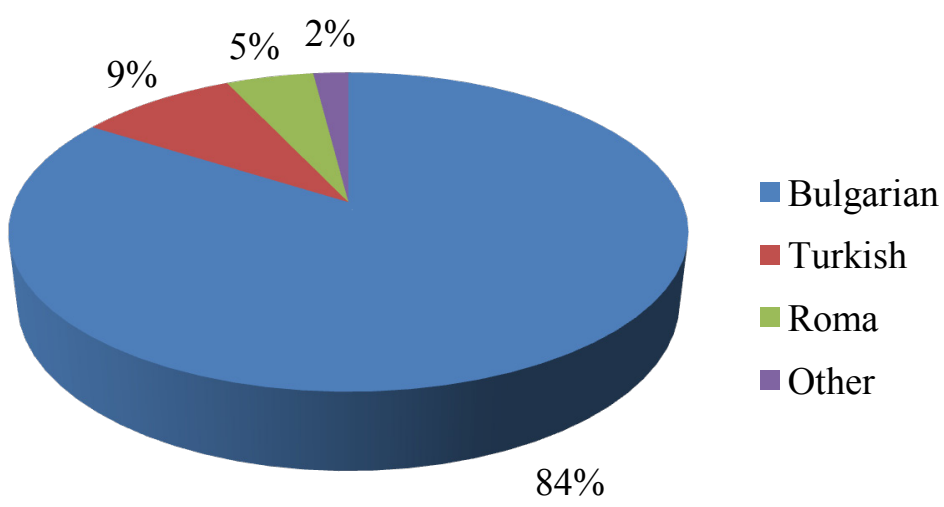

Figure 2.2: Ethnicities in Bulgaria.

Data source: CIA 2011 


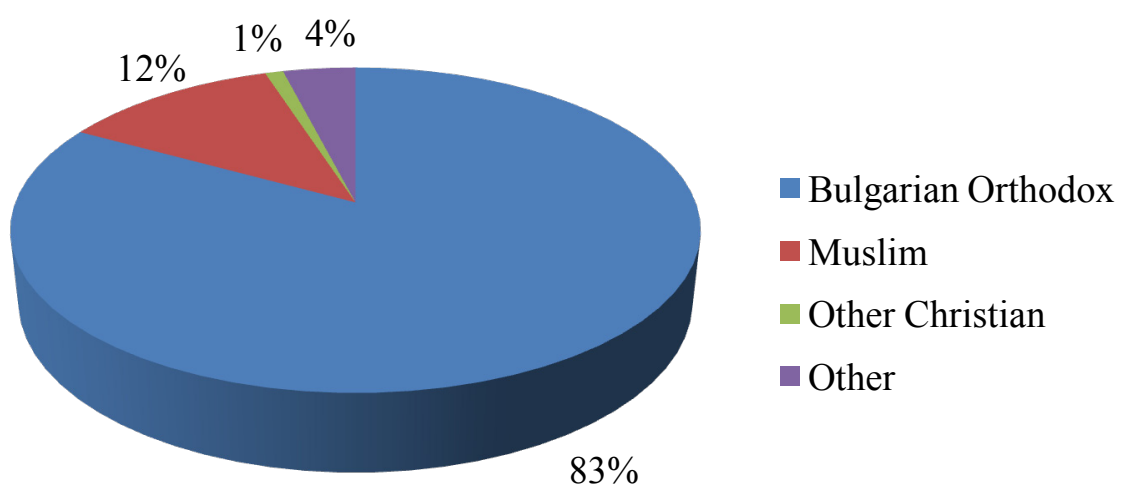

Figure 2.3: Religions in Bulgaria

Data source: CIA 2011

Tensions exist between the Orthodox and Muslim ethnicities; however, integration leads to an increased level of tolerance. The main animosities exist between the Roma and the rest of the Bulgarians. The Roma are viewed as welfare recipients who are lazy and do not deserve assistance. Their origins exist in India, but have been mixed with several Asian cultures throughout many centuries. The stereotype of a wandering gypsy would be true, but because of laws and regulations that exist in Europe, they have been forced to settle. This has proved difficult in regards to integration into European society and culture. Within Bulgaria, there are different levels of integration which in general are correlated with the caste to which they belong (United States Peace Corps 2008).

\section{Health}

The life expectancy of males in Bulgaria is 79.7 years and 77.7 years for females. Infant mortality is 9.4 deaths per 1,000 live births. The average family consists of two children leading to a negative 0.77 percent growth rate (CIA 2011). Comparatively, life expectancy for men and women in the United States is 75.9 and 80.9, respectively. Infant mortality is 6.1 deaths per 1,000 live births (CIA 2011). Heart disease, diabetes, and cancers, especially in relation to alcohol and smoking are prevalent. Most Bulgarian's cannot afford and do not access clinical preventative health care. Education of 
tuberculosis and other communicable diseases are of importance, as well as the need for vaccinations (WHO 2011).

\section{Economy}

As of 2009, the gross domestic product (GDP) was estimated to be USD 48.7 billion. Per capita GDP was USD 6,423. Unemployment was 10.1 percent in December of 2010 (European Commission 2003). Most people work in the services (64.9\%), industry (27.6\%), and agriculture (7.5\%) sectors (CIA 2011).

In 2009, due to the world economic downturn, Bulgaria experienced a five percent decrease in the GDP. Prior to the economic downturn was a period of growth from foreign investment. Corruption in public administration, a weak judiciary, and the presence of organized crime are problems that the economy has yet to overcome (CIA 2011).

Tourism has been identified as an area that many regions of the country desire to develop. This includes the Black Sea coastline, mountain resort areas, and other historical sites. Low standards of living combined with lack of jobs in Bulgaria have accounted for the emigration of many of the educated youth in Bulgaria into larger cities. The accession of Bulgaria into the EU in 2007 also allowed for movement to other member countries for work. In 2001 it was estimated that 700,000 people had left Bulgaria since the fall of communism and that 12 to 15 percent of the population at that point also intended to emigrate (Crampton 2005).

\section{Geography}

Bulgaria is located in the southeast corner of the Balkan peninsula of Europe and is slightly larger than Tennessee in area (CIA 2011). Its location is advantageous for tourism as it lies to the north of Greece and Turkey with close proximity to the Aegean Sea and borders the Black Sea (Figure 2.4). Balkan, an old word used for mountains throughout the peninsula, indicates the topography of the country. There are four distinct mountain ranges intersecting Bulgaria. The Rhodope and Pirin mountains are parallel to each other and run south to north from the southeast corner of the country. The Stara 
Planina, also known as the Balkans, cut through the country lengthwise from east to west. The Rila Mountains, another small range, however the highest, are located in the western part of the country near the capital.

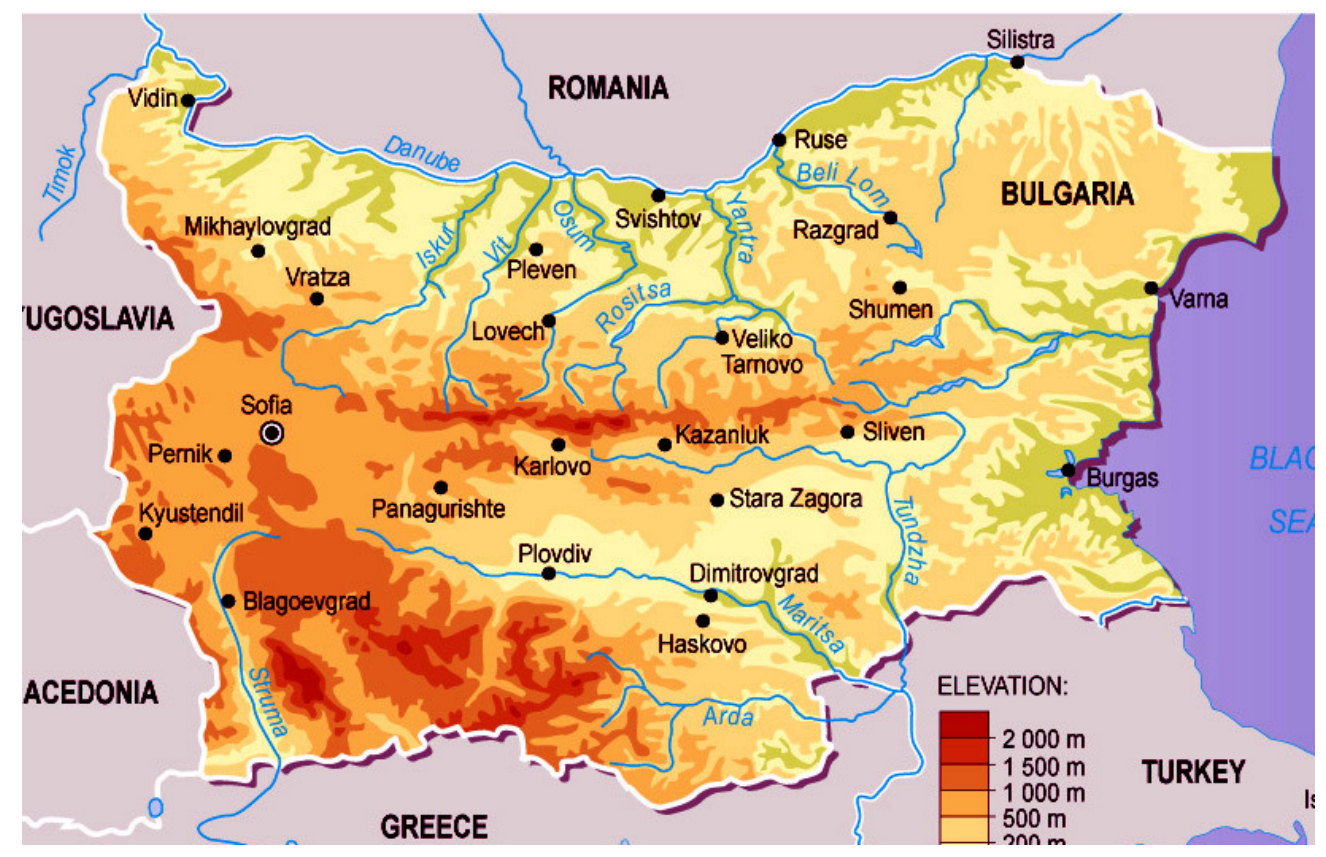

Figure 2.4: Topographic map of Bulgaria.

Source: UNEP/GRID-Arendal, Philippe Rekacewicz 1998 (See Appendix A) 
A person can travel from the peaks of the mountains near the western border to the sea shore on the eastern border in a day's drive in Bulgaria (Figures 2.5 and 2.6). It is also located close enough to the Mediterranean Sea that the southwestern part of the country is influenced by Mediterranean weather patterns. Located in the central and eastern part of the country are the plains which have fertile soil and are popular for growing roses and sunflowers. The primary causes of natural disaster are earthquakes and floods.

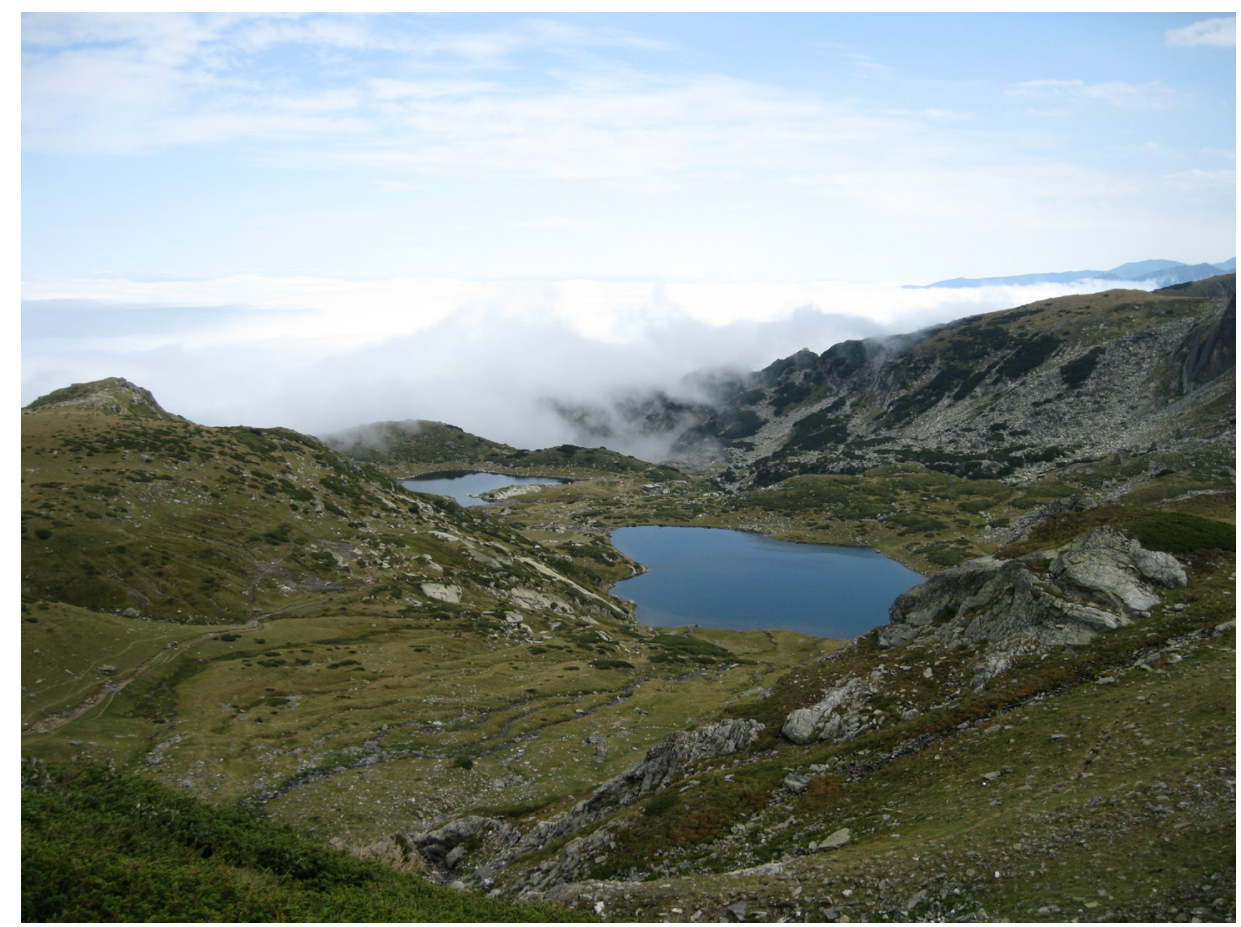

Figure 2.5: Seven Rila Lakes in the Rila Mountains, Bulgaria. 2,500 meters Photo: Callie Bertsch 


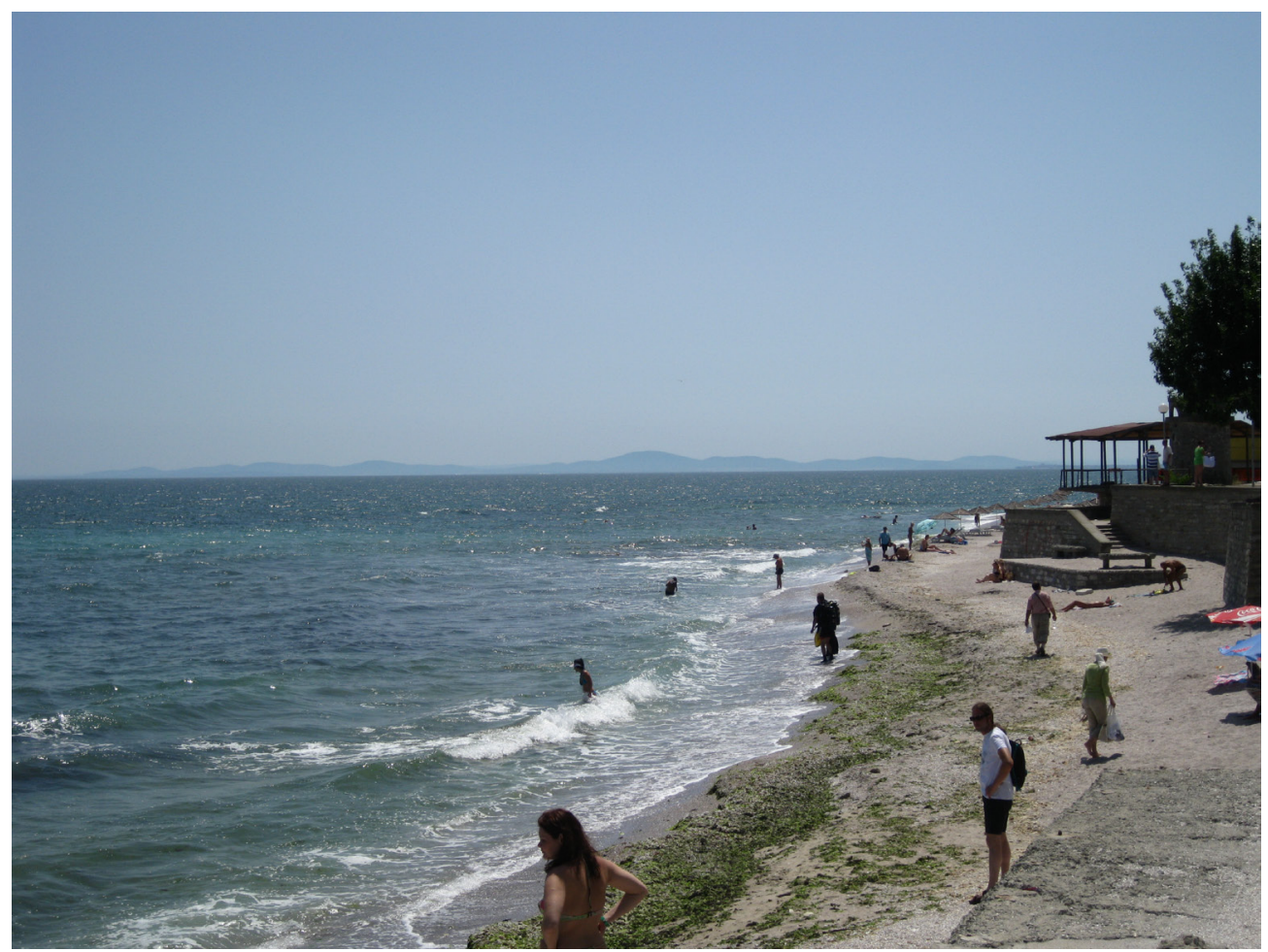

Figure 2.6: Black Sea coast near Nessebar.

Photo: Callie Bertsch

\section{Environmental Issues and Policies}

Environmental concerns in Bulgaria include air pollution in larger cities from vehicles and coal burning heating systems. Waste and recycling programs in the cities exist, but are not used or adequate enough to deal with the amount of refuse. Waste is dumped along the side of roads and burned. Pollution of raw sewage in waterways is also of concern, especially into the Danube River and rivers that flow into neighboring countries (CIA 2011). Pollution in the Black Sea, illegal building along shorelines, deforestation, and soil contamination are other areas of concern.

Environmental policies that exist are usually not followed. In many areas, mayors allow building on protected sites for a kickback. The existing departments, such as forestry, disregard current guidelines and management strategies for the sake of economic gain. An environmental mindset is beginning to take shape in some of the larger cities, 
but is not evident in the rural areas. Natura 2000, which was established by the European Union for member states, required setting aside protected natural areas (European Commission 2003). However, these protection rules are not followed because of corruption or are not feasible.

The Ministry of Environment and Water in Bulgaria has listed its priorities as completion of wastewater treatment plants, coping with water-supply problems, reducing soil erosion, and preventing landslides and sea abrasion. Furthermore, it is stated that it is committed to reducing trans-boundary air pollution and smog in cities by using unleaded petrol and placing restrictions on worn-out cars. Lastly, there is a desire to draft legislation that will not allow the country to be a disposal site for imported nuclear and chemical waste. Bulgaria plans to offer incentives for investments in power plants that are fueled by alternative energy (BG MOEW 2011).

Against this background of rich history, corrupt government, and rapid transition exists a nation of people who have inherited a culture and pride that is tied to the land and what it has to offer them. In Bulgaria, there exist traditional folklore dances that imitate the actions of the lifestyle of the people living there. Depending on the region, the movements imitate planting, growing, and cultivating the necessities of life. One of these regions is the Municipality of Garmen. The next chapters will look at how the people who live in Garmen are economically and culturally bound to the land, specifically through non-timber forest products (NTFPs). 


\section{Chapter Three: Study Area Background Municipality of Garmen}

\section{Geography}

Garmen is located on a section of the Dubrash Mountain Ridge, a part of the western portion of the Rhodope Mountains. There are 16 villages throughout the municipality; however, none of the villages are located in the northern part of Garmen because of the mountainous terrain. It is located on a section of the Gotse Delchev Field, which is a flat valley separating the Rhodope Mountains from the Pirin Mountains. Many of the villages are in close proximity to each other, but reaching them is difficult because they are separated by deeply cut river valleys (Figure 3.1) (United Nations Development Program 2006).

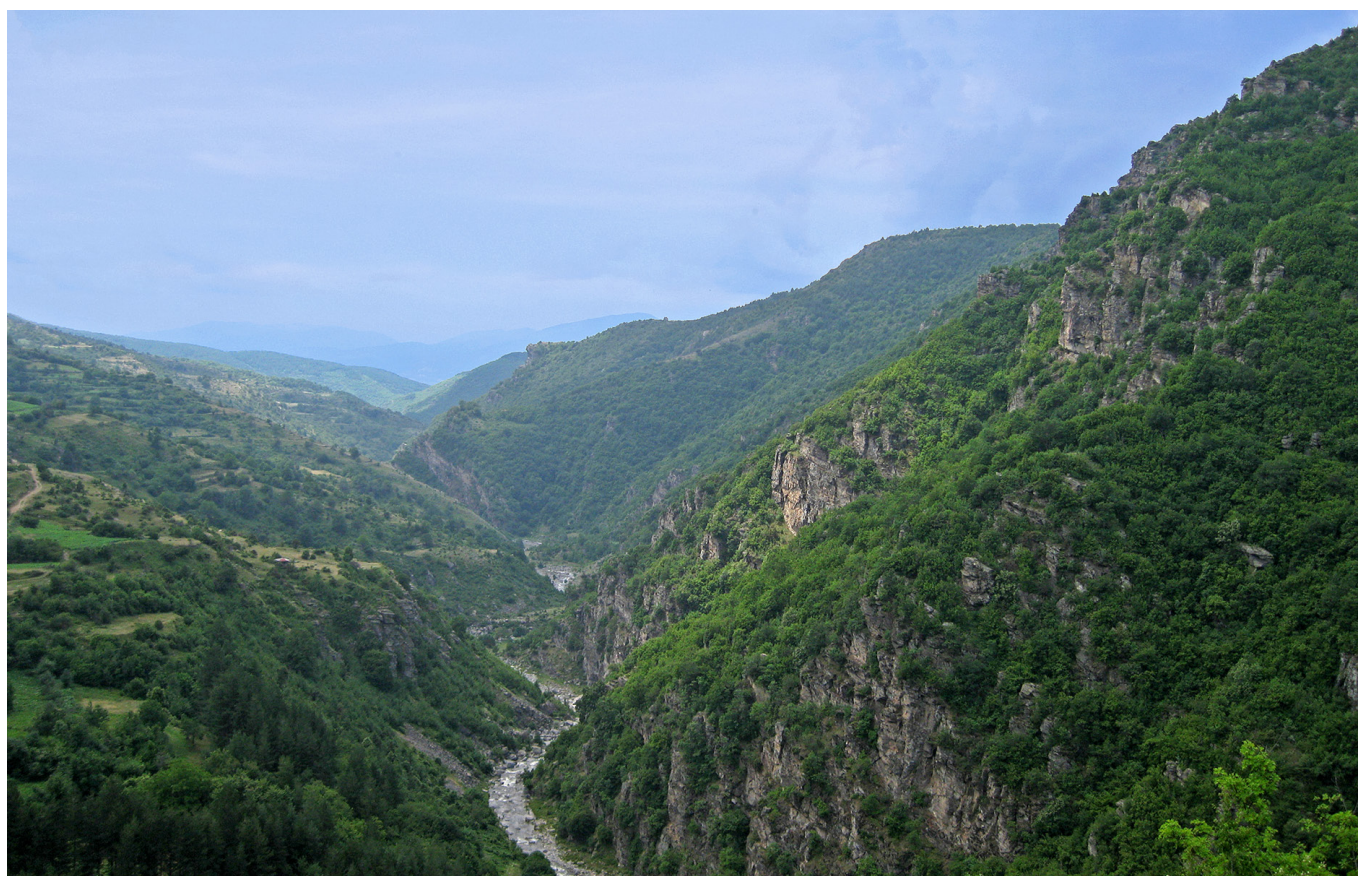

Figure 3.1: River Kanina Gorge, Municipality of Garmen.

Photo: Callie Bertsch 
The average elevation is 1,164 meters with the highest peak reaching 1,938 meters and the lowest point at 500 meters along the Mesta river valley which is located in the Gotse Delchev Field. One of the river valleys has hot mineral springs which are used in bottling water and as a popular tourist destination for people from all over Bulgaria. Garmen has incredible rock formations that exist in higher elevations as well along the rivers. One area has recently been classified by archaeologists to be an ancient Thracian worship site, dating to the fifth century B.C., with large images, human footprints, sun dials, and thrones engraved in stone. Many of the rocks also appear to have shapes resembling faces and animals (Figure 3.2).

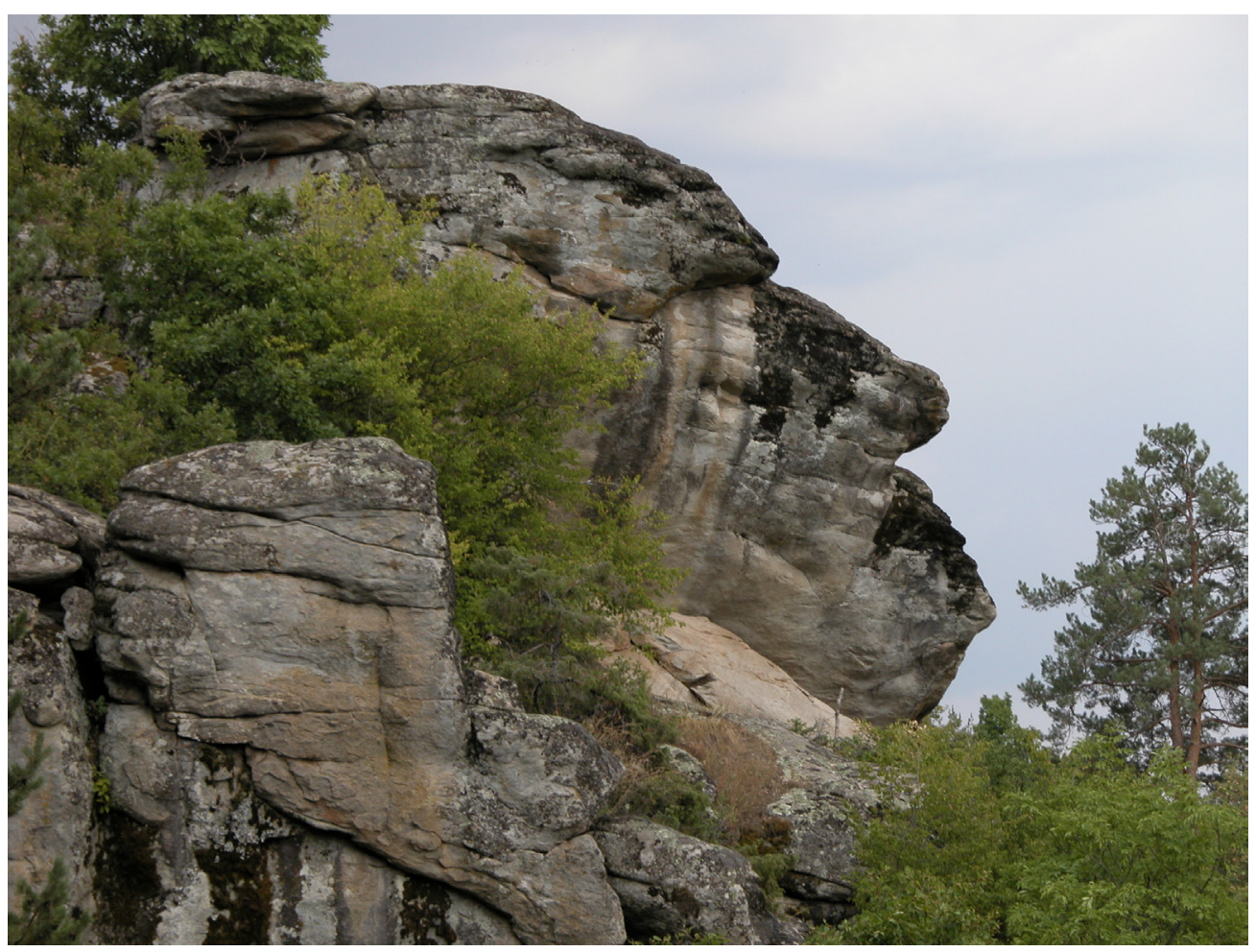

Figure 3.2: Stone head at ancient Thracian worship site in Garmen. Photo: Callie Bertsch 


\section{People}

There are 16 villages throughout Garmen. Five of these villages are home solely to Bulgarian Muslims. There are two Turkish Muslim villages which also have populations of Roma. Four villages have only Bulgarian Orthodox Christian, but the combined populations of these villages is 435 people. There are four more villages that have a combination of Christian, Bulgarian Muslim, and Roma populations. Garmen, the seat of the municipality, is predominantly Christian, except for an unregulated Roma neighborhood on the edge of the village (Municipality of Garmen 2006). The previous chapter noted that Bulgarians are the dominant ethnicity followed by Muslims and Roma people in Bulgaria. In Garmen, the dominant ethnicity is the Muslim, followed by Bulgarians, Roma, and Turkish, respectively (Figure 3.3).

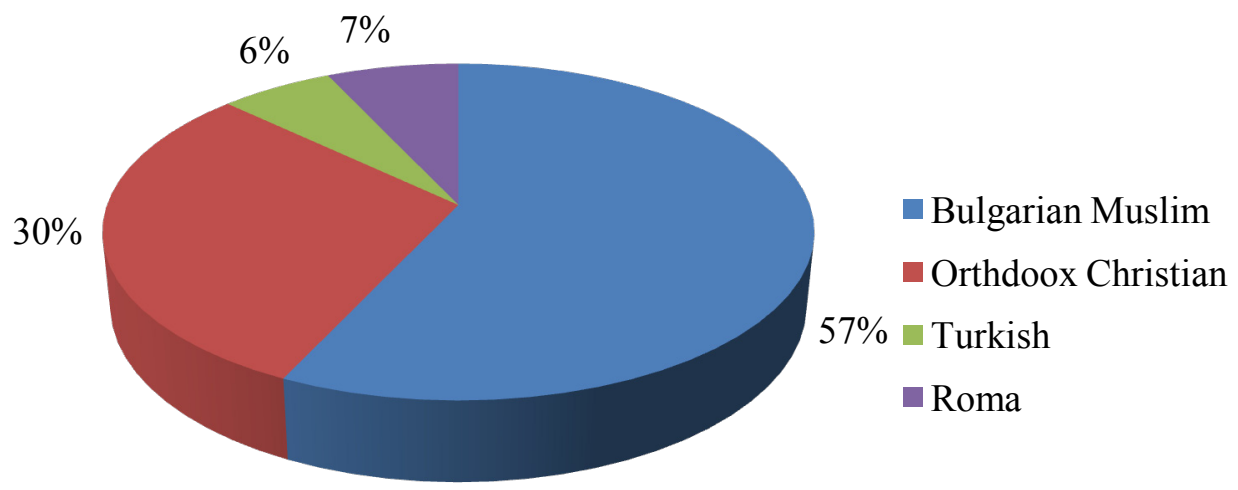

Figure 3.3: Ethnicities in the municipality of Garmen.

Data Source: Peace Corps 2008 
During the time of the Ottoman Empire, many Orthodox Christian Bulgarians converted to Islam. Conversion allowed people to retain their property, to reduce tax burdens, and to enjoy the privileges held by the dominant religion. Additionally, some Christian villages were enticed into Islam by offers of freedom to loot and pillage local church or monastic property. Lastly, during the late part of the $17^{\text {th }}$ century there were cases of enforced, violent conversion. These instances occurred in the Rhodope Mountain region where Garmen is located. The Bulgarians who converted to Islam during the Ottoman Empire are known as Pomaks, which is a term still used today (Crampton 2005).

The demographic distribution of ages is shown in Figure 3.4. In previous years, the population declined steadily because of negative birth rates and immigration to other European Union countries for work. However, in 2010, Bulgarians who had migrated and were living throughout the EU were forced to return home because of job losses that were a result of the global economic crisis. The effect was a population increase in the rural areas of Bulgaria. The current population of Garmen is 16,861 with the largest village having a population of 2,901 people (Municipality of Garmen 2010a).

In comparison, the 2006 age demographics are shown in Figure 3.5 for all of Bulgaria. Garmen has a higher proportion of youth when compared with the rest of Bulgaria. The Muslim villages have higher percentages of youth, who remain at home to help with agriculture. They also have higher proportions of females who marry at a young age, often while they are still in high school. 


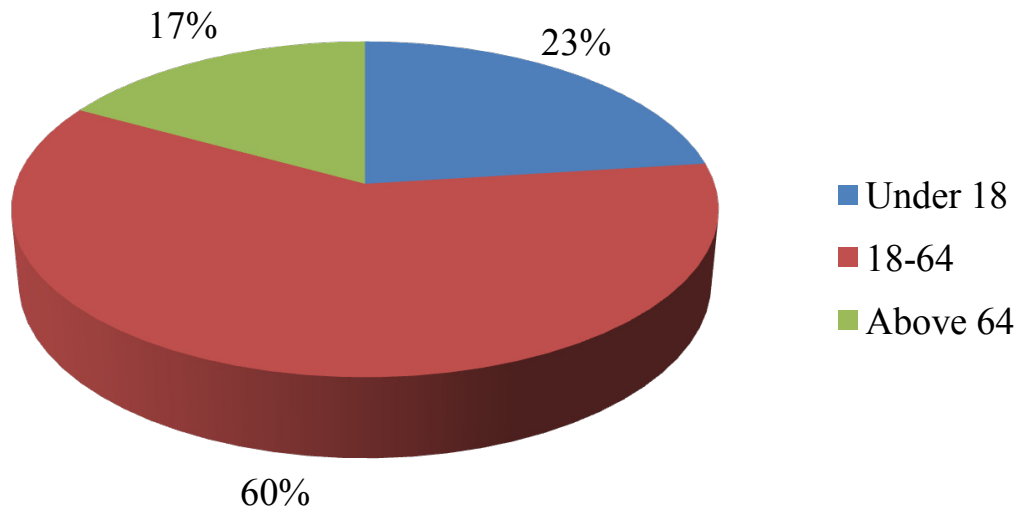

Figure 3.4: Age demographic in Municipality of Garmen.

Data Source: Municipality of Garmen 2006

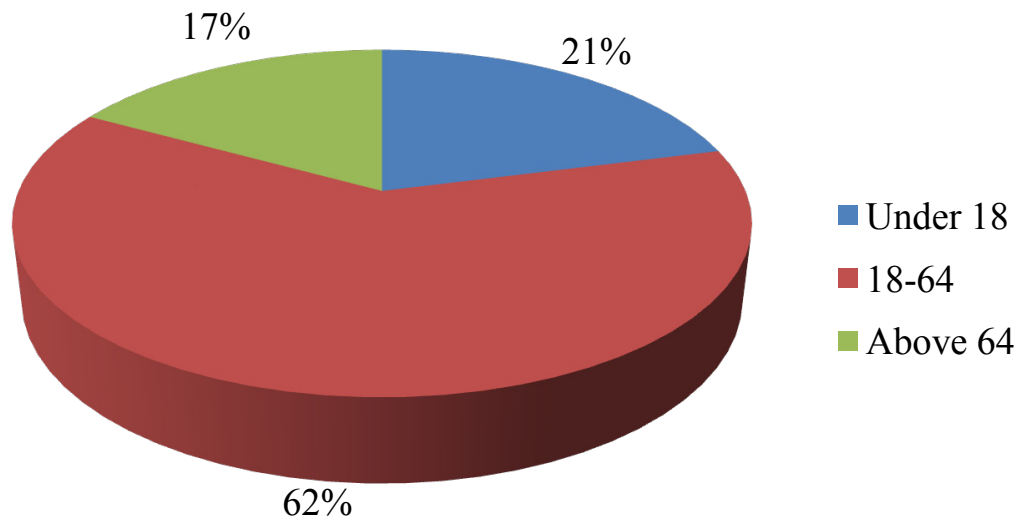

Figure 3.5: Age demographics of Bulgaria.

Data Source: U.S. Census Bureau (International Data Base) 2006 


\section{Economy}

Garmen has a high unemployment rate, approximately 11.8 percent, when compared to the district in which it is located. The chief livelihood of people in Garmen is agriculture; however, in many families, people may tend to the fields and also maintain other types of income generating activities (United Nations Development Program 2006) The following figures indicate other sectors in which people are employed as of 2006 (Figures 3.6 and 3.7). The tailoring industry, which is defined by factories where clothing is sewn for western companies, and education are the dominant workforce sectors. In general, women are more frequently employed than men because of the main sectors of employment. Most of the tailoring factories are located in the Muslim villages (Municipality of Garmen 2006). Forestry and logging are separated and listed in different categories because forestry refers to the people working for the local forestry department and logging are the private companies that do the timber harvesting.

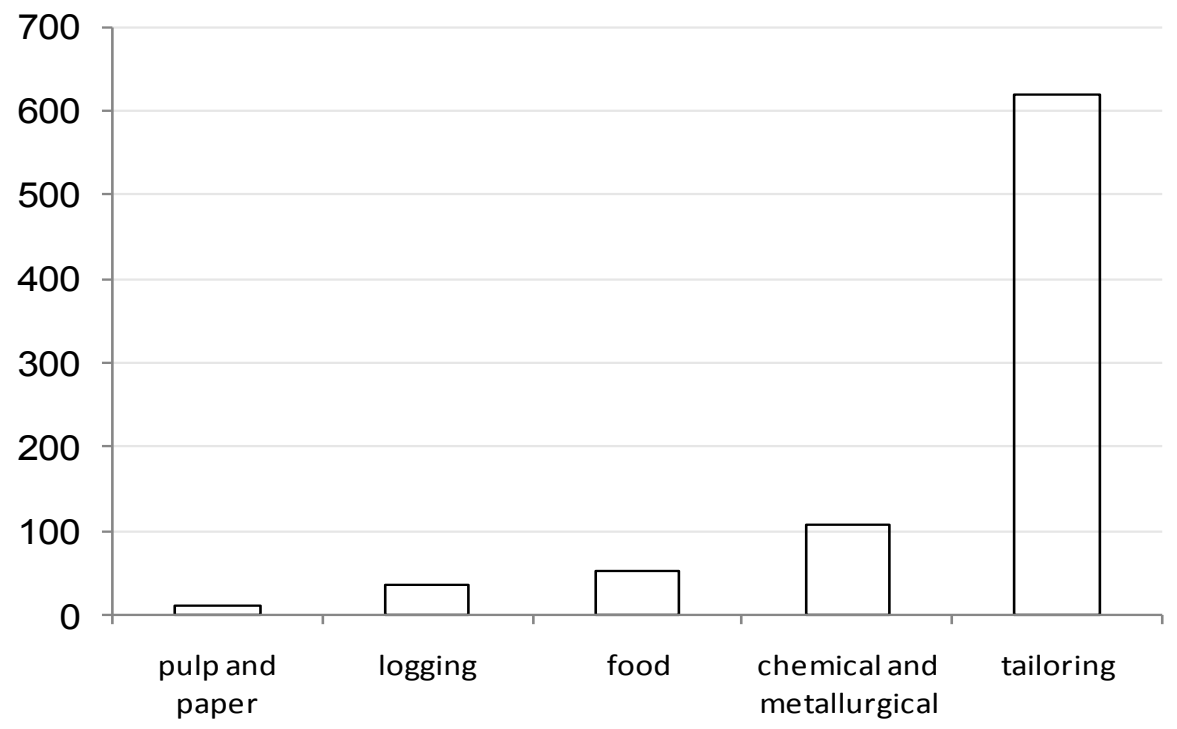

Figure 3.6: Number of Residents in Garmen employed in the industrial sectors. Data Source: Municipality of Garmen 2006 


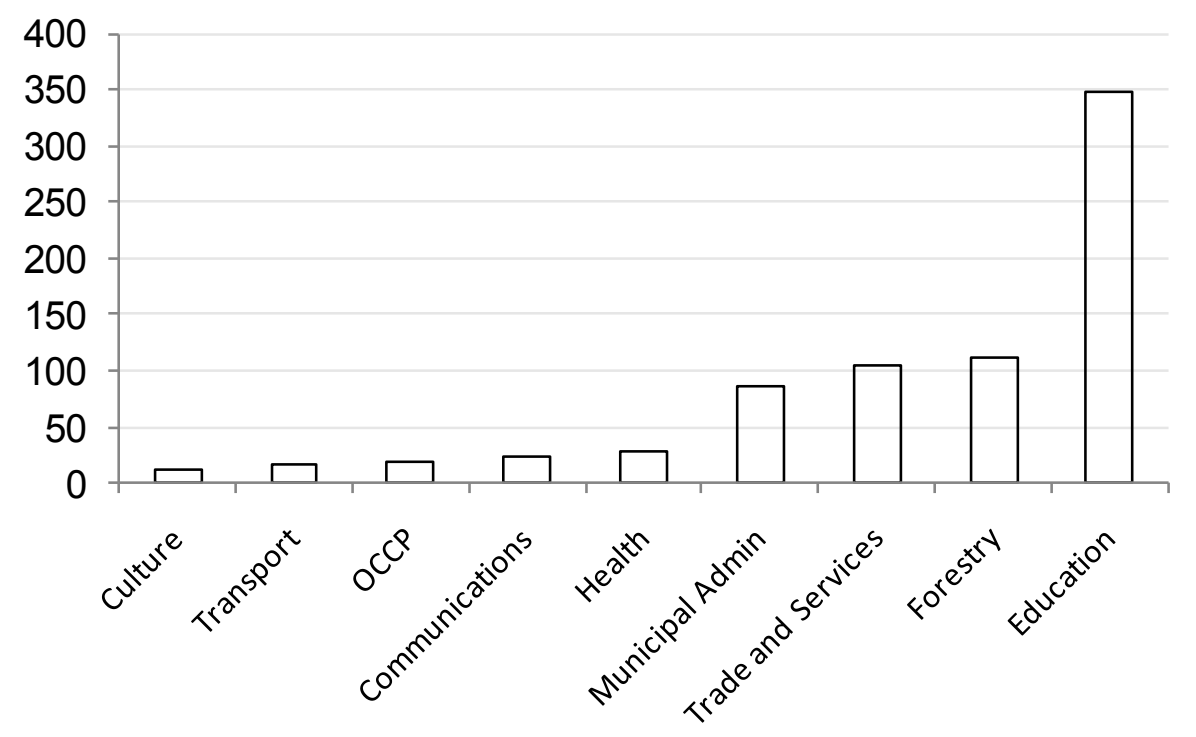

Figure 3.7: Number of Residents in Garmen employed in non-industrial sectors. Data Source: Municipality of Garmen 2006

The dominant agricultural crop is tobacco (Figure 3.8). Even if they are employed elsewhere or registered as unemployed, the majority of the Muslims and some of the Bulgarians have agricultural fields and plant tobacco and potatoes. Agricultural fields are located near villages, but often a difficult walk from a person's home because available flat land is scarce in the mountains. Land that is owned is a result of the forest restitution law enacted in 1997 (Cellarius 2001). The land is typically allocated for gardens, livestock, and agriculture. Gardens are an integral part of everyday life of people in the rural villages. The produce from the gardens is consumed fresh during the summer and conserved for the winter. People living in the rural regions would not be able to afford the produce that their gardens provide if they were purchased at a market. 


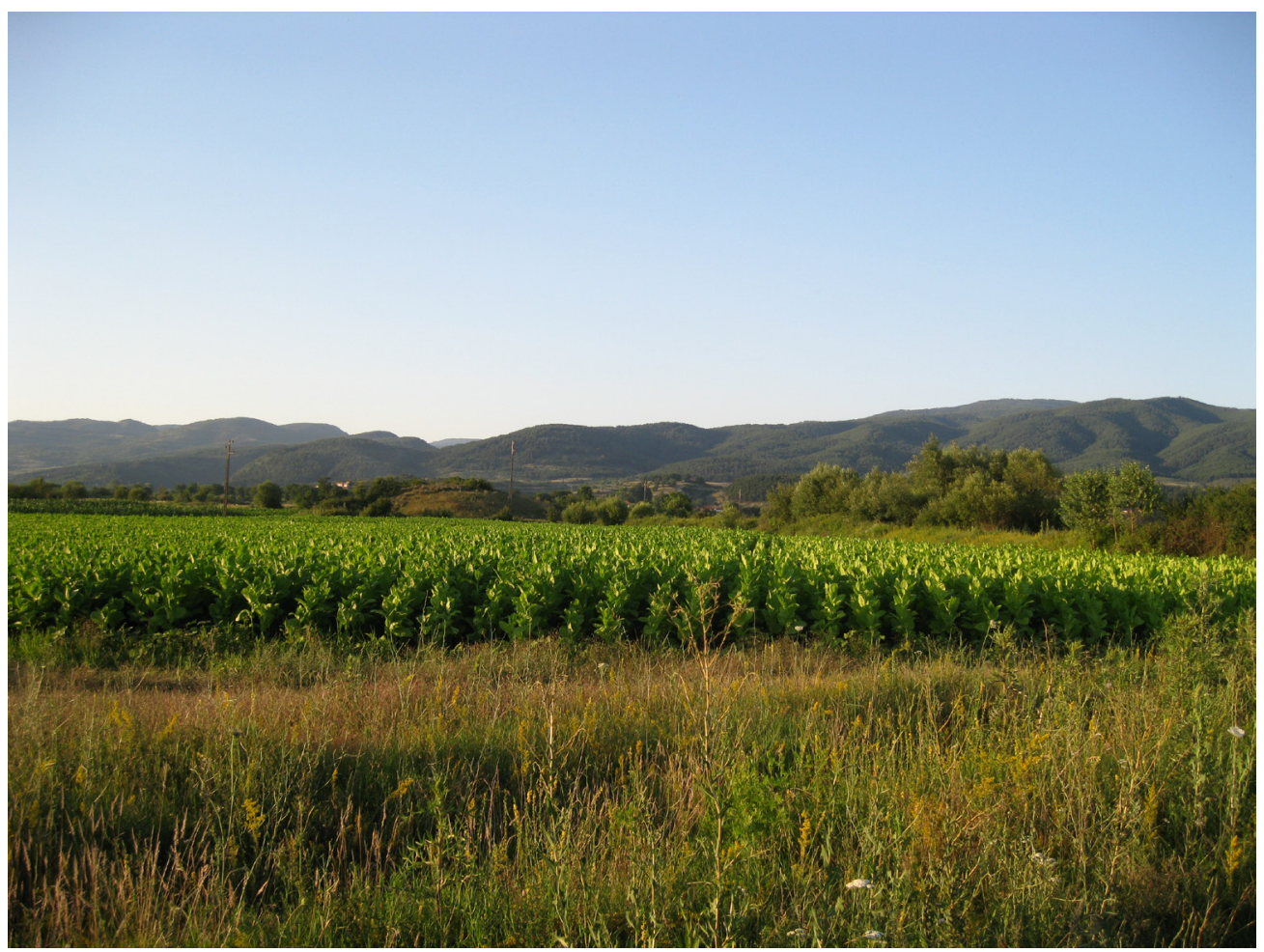

Figure 3.8: Fields of tobacco near the village of Garmen.

Photo by: Callie Bertsch

\section{Climate}

The climate is moderate continental with a strong Mediterranean influence. There are four distinct seasons with mild temperatures in the winter and high temperatures in the summer. High elevations regulate temperatures and allow for snow cover during the winter. The summer has an average temperature of 18 degrees, but may reach 40 degrees. The average amount of moisture received each year is $620-780 \mathrm{~mm}$. Winter is the wettest season, followed by spring. Summer and fall are dry, sunny seasons (Municipality of Garmen 2010b). 


\section{Forests}

The forested land in Garmen covers 29,025 hectares or 70 percent of the total land area (Bogdanov and Stiptsov 2007). Coniferous trees comprise 24,030 hectares, or 83 percent, of the government owned forest. The rest of the forests are managed as deciduous, seedlings, regeneration, and scrubland (Bogdanov and Stiptsov 2007). Ninety-eight percent of the forested territory is state land with the rest divided between private owners, religious groups, and the municipality (Municipality of Garmen 2010b).

Garmen has the largest forest service in the country. The Tumnata Gora (The Black Forest) is located in the western part of Garmen and was declared a natural reserve to protect the old spruce, beech, and fir forests (United Nations Development Program 2006). The area is only accessible when accompanied by an employee of the forestry department. Other notable trees are centuries-old sycamore trees which no longer exist in the forest, but have been preserved in several of the villages.

The dominant tree species are pine, spruce, and white fir. Beech and oak are also present. From early June through October, different species of NTFPs are found in the forests and meadows. The berries, herbs, and mushrooms are important for subsistence, medicine, and parts of the culture that have been included in local traditions and folklore. The unemployed and retirees may completely rely on it for income and subsistence. 


\section{Chapter Four: Methods}

Non-timber forest products (NTFPs) are an integral part of the everyday life of many of the inhabitants of the southwest region of the Rhodope Mountains. One objective of this study was to determine the economic and landscape concentration of NTFPs and how this has changed in the past twenty years in the region of Garmen. The main objective was to gauge the cultural and economic significance of NTFPs in the lives of the people who live there. Three methods of data collection were used: participant observation, semi-structured interviews with people in the study area, and semi-structured interviews with people outside of the study area. The three methods were chosen due to the qualitative nature of the study. The element of trust played an important role when gathering information; informants felt more comfortable as they elaborated on their insights.

Participant observation was accomplished by living and working with, as well as learning the language of the people in the study area (Bernard 2002). Casual conversations about NTFPs were recorded in a journal and participants were accompanied in the field as they collected products. This allowed for extensive information gathering on the collection and use of NTFPs by the people and the types of

products and areas in which they are collected. A level of trust was built with community members including people who relied on NTFPs and members of the local forest service. Participant observation was an invaluable method of data collection in order to confirm the accuracy of information given during the interviews. In some cases, the observations also added information that the participants may have forgotten to give during the interview such as specific species that they collected.

A semi-structured, open-ended method of interviewing was used (Bernard 2002). The interview was guided with a survey (Appendix B) which had been approved by the Institutional Review Board (IRB) at Michigan Technological University (Protocol M0596). The questions allowed the participants to express their opinions on collection habits and reasons for land changes and transformations. Participants were told that for the purpose of this study, NTFPs were defined as any herb, berry, or mushroom that they 
collect in the forest. The interviews were performed in Bulgarian and tape-recorded for later review; notes were taken in the field when participants were accompanied as they collected NTFPs.

A purposive sample of people was chosen for the interviews based on observations of people who were most active in the collection of the resources as well as their knowledge of them (Guest et al. 2006). Participants were chosen from each ethnic group represented in Garmen and from three communities. For an added level of trust, Peace Corps Volunteers who lived in two of the communities were present for the interviews.

The interviews were conducted with individuals, but in some instances group interviews were carried out, primarily with women. There were never more than three people interviewed at a time in this situation. Each person answered the questions individually as well as collectively. This proved valuable as it increased the amount of information provided because each person helped the other with thoughts they may have forgotten. In total, 23 people were interviewed. Interviews were performed until a point of saturation of information had been reached among each of the ethnicities (Guest et al. 2006).

The last method of data collection was using the same semi-structured, openended interview with two types of people who lived outside of the municipality. The first type was people who lived nearby and collected products in the area being studied and the second type were a group of Roma people who lived in the Southwestern Rhodope Mountain area, near but outside of Garmen. The second type was chosen to be interviewed because the Roma located in Garmen are of a lower caste who travel into the mountains during the summer and set up camps to collect NTFPs.

The Roma people's native language is Romani. Different caste levels also speak different dialects of Romani and different levels of Bulgarian. It was difficult to interview the Roma in Garmen because of these constraints. To remain consistent with the interview timing, the Roma people chosen to be interviewed travel less frequently, spoke higher levels of Bulgarian, and had a known Peace Corps Volunteer in their village 
for the element of trust. A Roma native was also in attendance to act as a translator, if needed.

The participants ranged in age from middle school aged children to retirees and were also comprised of eight males and 15 females. This provided a valuable insight into where and how people collect the NTFPs and their opinions on the changing eco-system in which they collect them as well as changing economic values. The interviews lasted from 15 to 60 minutes. The interviews followed a standard procedure except for one woman who collected and sold non-timber forest products at the local market and was chosen to be interviewed at her selling stand in the market. She had no prior contact with an American or a Peace Corps Volunteer and her responses were not as detailed and a skepticism of the interviewer was present.

Lastly, information from the journals and interviews were analyzed using a topical coding scheme (Bernard 2002). The data was first separated and coded by ethnicities and species collected. Under these two main themes, other main topics and repetitive ideas were grouped including: culture and traditions, economics, changes in the forest ecosystem, habitats where species are collected, conflicts when collecting NTFPs, and opinions of why changes have occurred. 


\section{Chapter Five: Results and Discussion}

The results of this study can be grouped under five broad topics. The first is that the three different ethnicities represented in the study were found to collect NTFPs for varying reasons. It is important to recognize the reasons in order to understand how the changes in the forest systems and broader economic changes in their society and globally affect each group. The second topic is the specific information about the habitats, seasons during which the NTFPs are collected, and the importance of them in the home and market. This is important in understanding the ecological relationship they have with the forest and how changes in the forest affect the NTFPs and the livelihoods of the people who collect them.

The third topic is the changes that have occurred in the forest and in the economic status of the NTFPs in the last twenty years. This also demonstrates the impact that the products have on the local people. Fourth, there are conflicts that exist among ethnicities, primarily between the Roma and Bulgarians at the buying stations for the mushrooms. Lastly, the participants of the study discussed the control of the forestry department on the management of the forests and how it affects the NTFPs.

\section{Ethnicities}

Roma

In a study completed in 2001, interviews were conducted with Roma people in Eastern European countries regarding their self-perceptions of life during communism and during the year 2000. The Bulgarian Roma interviewed reported that in 1988, 14.7 percent considered themselves to be either poor or very poor. In 2000, 66.2 percent considered themselves in the same categories. Furthermore, 16 percent had below average income in 1988 compared to 80.3 percent in 2000 (Szelenyi 2001). The older Roma participants of this study also recalled a more stable life during communism when the men were employed by the state, often doing various jobs with the forestry department. 
Throughout the past twenty years, the discrimination against the Roma and their inability obtain jobs has increased. Many of the Roma are forced to live on welfare, collect scrap metal, and work in other countries in the agricultural sector. The Roma travel to larger cities such as Sofia and Athens for the purpose of pick-pocketing and there is a larger problem of human-trafficking among the young Roma girls and women throughout Europe (Vassilev 2004).

Collecting NTFPs has become an additional, viable source of income for the Roma. Roma families rely on NTFPs to supplement their income throughout the summer months. All of the Roma interviewed said that mushrooms and profitable berries are ninety percent of their income during the collection season. During a 100-day collection season, they may collect 15 to 25 kilograms of mushrooms each day. One type of mushroom, Patchikrak (Chanterelle), previously sold for four leva per kilogram (1.000 lev is equivalent to 0.722 USD per www.x-rates.com accessed on March 20, 2011). The earned income is 60 to 100 leva for one day. The average monthly income for all ethnicities in Bulgaria was 320 leva per month in 2007 (United States Peace Corps 2008). Note: In the Bulgarian language, lev is used in the singular form and leva is plural.

The average household size of each Roma family represented was between four and six people. The demographics included the mother, father, and children. Each family was also in the bezrabota (jobless) category, except for the only male Roma interviewed who is currently a student. All of the Roma interviewed for this study stated that they travel together in vans and buses with their family, extended family, and friends to sites up to 50 kilometers away from home. They camp in the mountains for days and weeks at sites where they have a preexisting knowledge of abundant NTFPs. Lower castes of Roma were spoken of who caravan using wagons and horses with 100 to 200 people. They travel with their entire village and will stay in the forests for the entire picking season, May through September and sometimes into October. 
Collecting NTFPs for Roma, especially the women, has become an important means of providing for their families. Because of this, they proved to have the most knowledge of NTFPs. For instance, they were able to identify 88 percent more types of mushrooms they collect than Bulgarian and Muslim people. They also described how disturbances in the forest would harm or benefit the growth of each species of mushroom as well as knowledge of specific habitats in which mushrooms are found.

The Roma sell what is collected to a local wholesale post, reserving one to two kilograms for personal use (Figure 5.1). From the local posts they are sold to larger wholesale bases which distribute them throughout Europe. Berries such as bilberry, cowberry, dog rose, and cornel-cherry are also a profitable source of income that the wholesalers will buy during late summer through early fall. All of the Roma collect herbs and other berries for personal use as a side activity.

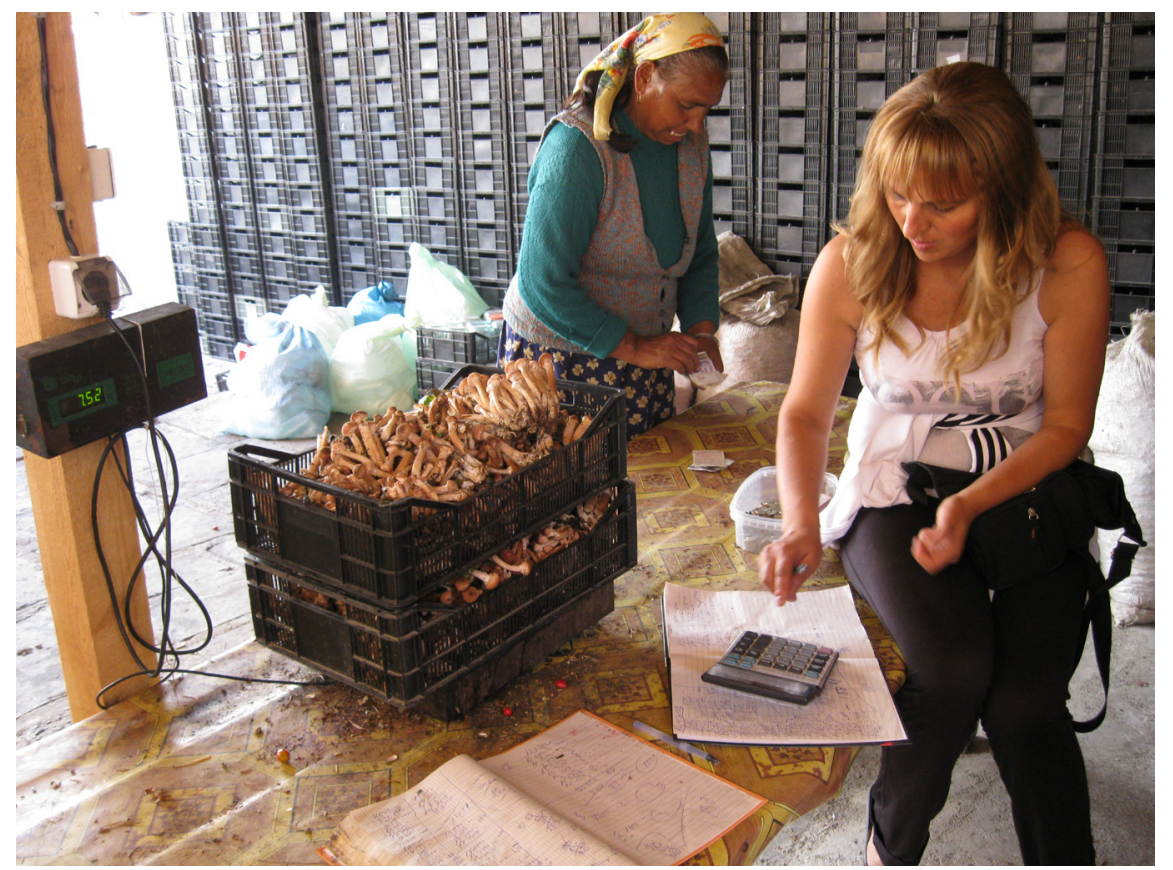

Figure 5.1: Roma woman selling mushrooms to a Bulgarian at the wholesale station in Rakitovo. Photo: Callie Bertsch 


\section{Bulgarian}

In contrast with the Roma, the traditional Bulgarians collected NTFPs as a hobby and for cultural purposes. One Bulgarian woman stated, "I remember going on hikes with my grandfather as a young girl to collect herbs, I enjoyed this activity and want to carry it on with my children." The Bulgarians interviewed were either employed or received pensions as retirees. They all live in households of three to four people which included the husband, wife and up to two children.

There was also an emphasis on the cultural value of having knowledge of specific health benefits of each herb and berry collected. Ekologichni chisti was a common phrase used, which means "ecologically clean". This was an important factor for the Bulgarians who collect NTFPs. They enjoyed the satisfaction of collecting berries and herbs for consumption, their healing properties, and the knowledge that they contained no added chemicals.

All of the informants stated that they either go to the forest to specifically find herbs that they know will cure a specific ailment or collection is a by-product of spending time on a hike or picnic with friends and family. They may travel up to 15 kilometers from home for this purpose. Herbs were the highest priority of NTFP that they collect. Berries were listed as their second priority and they collect mushrooms if they happen to see them in the forest. One Bulgarian man interviewed said that in previous years he collected berries and mushrooms to sell at the market, but this year the economy was bad and he was working a temporary job. 


\section{Muslim}

For the Bulgarian Muslim, the reasons for collecting NTFPs were a combination of the traditional Bulgarian and the Roma. Half of the Muslims were bezrabota (jobless), the others were employed as teachers or retired. Their reliance on the forest is for subsistence, medicinal, economical gain, and to preserve cultural values. All of the Muslim villages are located higher in the mountains than the Bulgarian or Roma villages.

Half of the Muslim families in the study consisted of grandchildren living with their grandparents as the parents were working in other countries within the European Union or the United States. Like the Roma and traditional Bulgarians, each of the Muslims stated that they know the exact locations in the forest to find the herb, berry, or mushroom they are looking for and its use. Three-fourths stated that, like the Bulgarians, they collect NTFPs while in the forests on hikes and picnics (Figure 5.2). However, they also stated that if they are in need of money, especially towards the end of the month, they will purposely collect the profitable NTFPs to sell at the market. The remaining 25 percent collected to earn an income, like the Roma.

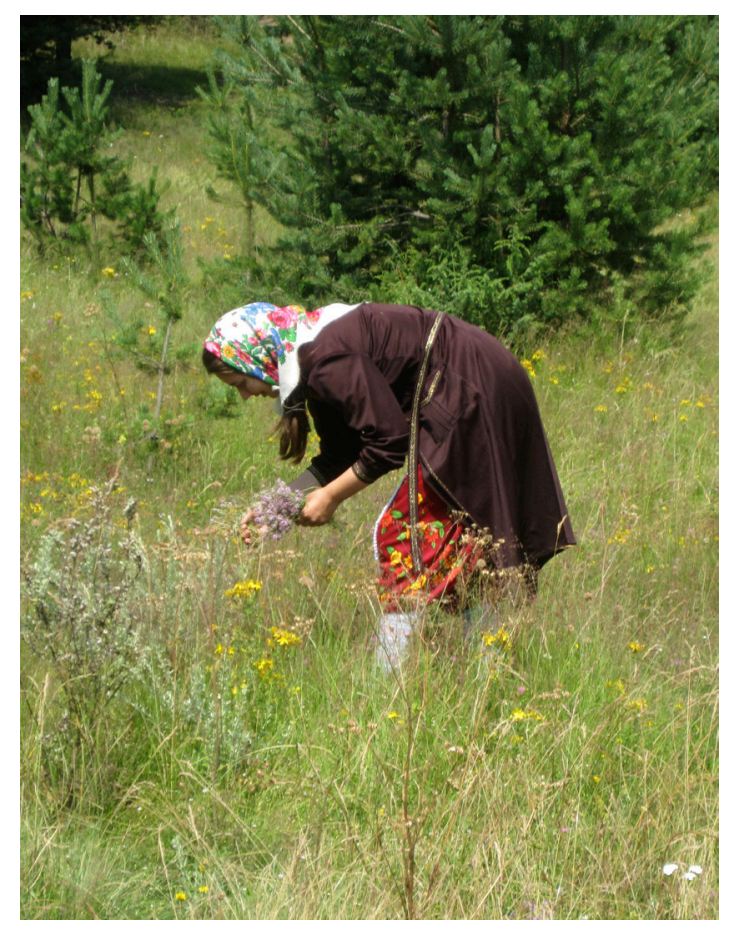

Figure 5.2: Muslim woman collecting herbs while on a picnic. Photo: Deborah Bloom (See Appendix A) 
One informant stated, "We are mountain people, this is what we do," in reference to the lifestyle of people living in these mountainous villages. Another man emphasized, "We don't drink alcohol, and in the winter we don't drink water or carbonated beverages, we collect the berries so we can have juice to drink." NTFPs for the Bulgarian Muslim are significant for their cultural purpose and medicinal properties as well as the income they can obtain from them.

\section{Species collected}

\section{Berries}

Eighty-six percent of all participants collect berries either for income or for use in the home. The remaining 14 percent who did not mention berries were ethnically Roma. This does not mean that they do not collect berries, but rather that they focused on the products that were of greater importance to them during the interview. When accompanied in the forest, the Roma collected berries for immediate consumption or for later use in the home, but they do not focus on this NTFP as it does not provide an economic profit. All of the ethnicities were observed to purposely focus their collecting on specific NTFPs, and collect other products as they found them in the forest.

Raspberries, blackberries, wild strawberries, cornel-cherries, bilberries and cowberries are of the highest economic value at the market. Bilberry and cowberry were collected most frequently because they bring the highest price at the market and are found most often in the forest (Table 5.1). During 2010, the price for all berries varied from two to three leva per kilogram throughout the late summer months.

Informants who collected berries for use in the home rated them as the highest importance and stated that they were used for making compotes, jellies, and juices (Figure 5.3). Those who collect berries for income stated that they can collect an average of 15 kilograms of bilberry and cowberry a day. They will freeze them as well, in order to have them throughout the winter. The leaves of all the berry plants may also be dried and used in teas for medicinal purposes. 


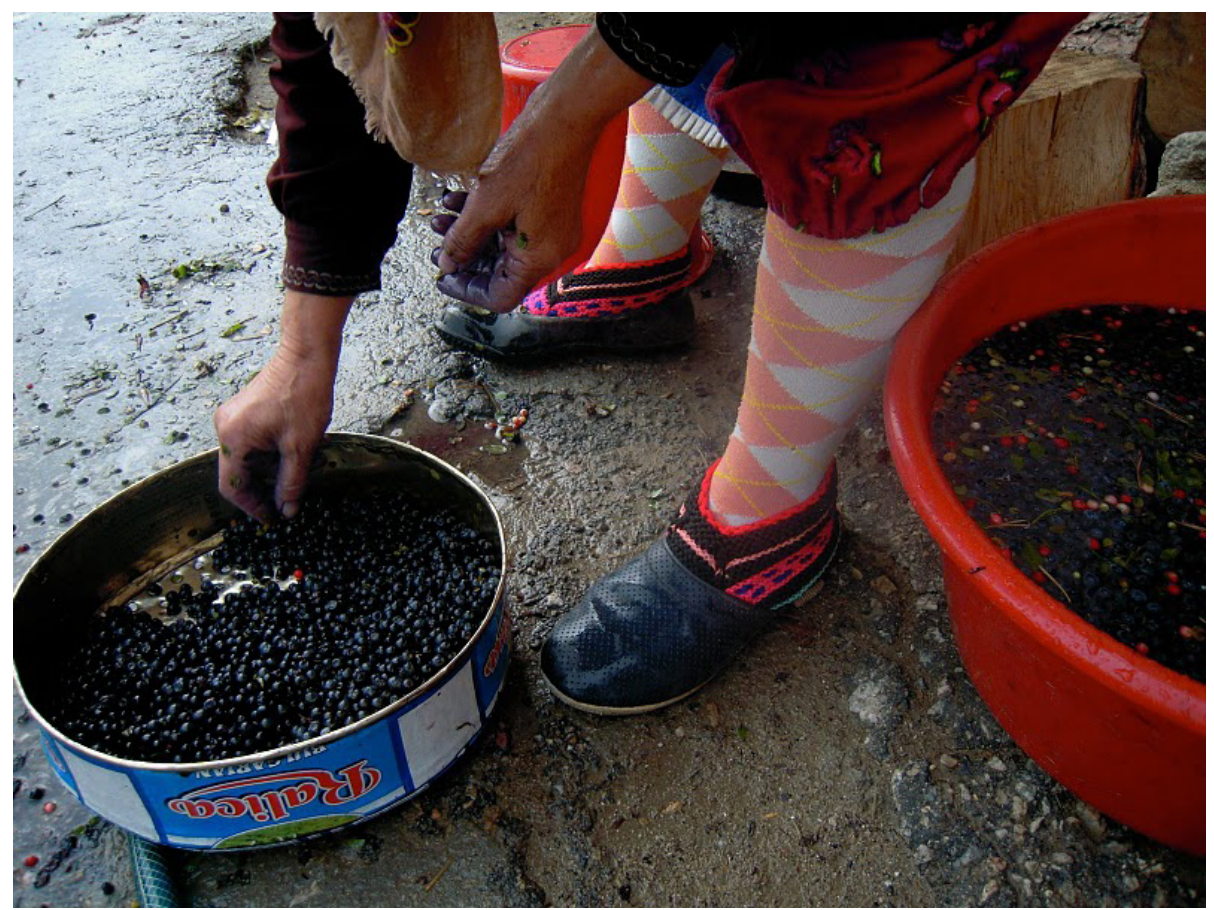

Figure 5.3: Muslim woman sorting through bilberries to make a compote. Photo: Kay Hannahan

The health purposes for which each of the berries was used were for vitamins although the informants stated that they use bearberry, juniper, and rose hip in teas for bladder infections, diabetes, and colds (Table 5.1). According to participants, the profitable berries have declined in quantity in the forest because of declines in the plant populations. This may be caused by logging in the forests which destroys the surrounding vegetation. Another explanation was given by a Bulgarian, "People have started using mechanized methods of collecting the berries, which destroys the plants."

Cowberry and bilberry are the only berries found in shady, forested areas (Table 5.2). The rest are all in sunny, open areas such as meadows; there was not a noticeable decline in abundance of species found in these habitats. The leaves are collected during late spring and early summer for teas and the berries are collected from late summer through early fall. All of the berries are used fresh or are preserved through freezing or conserving them. The leaves of the berry plants that are used for teas are dried. 


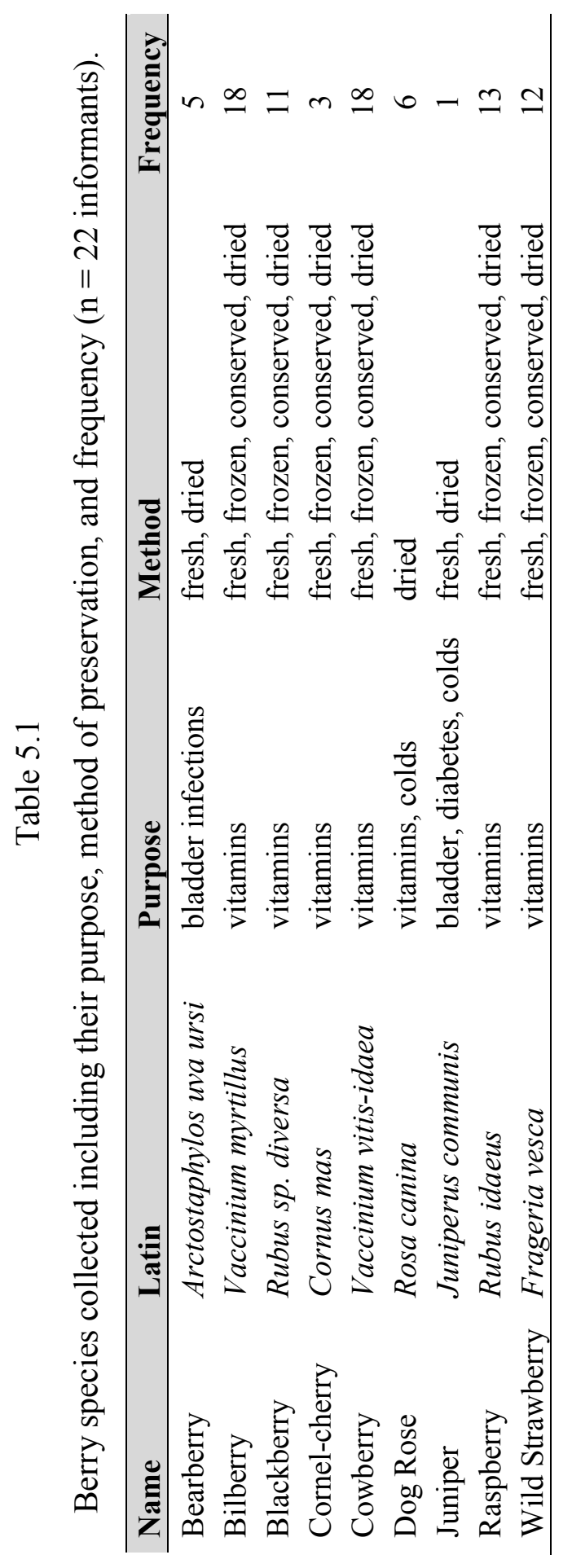




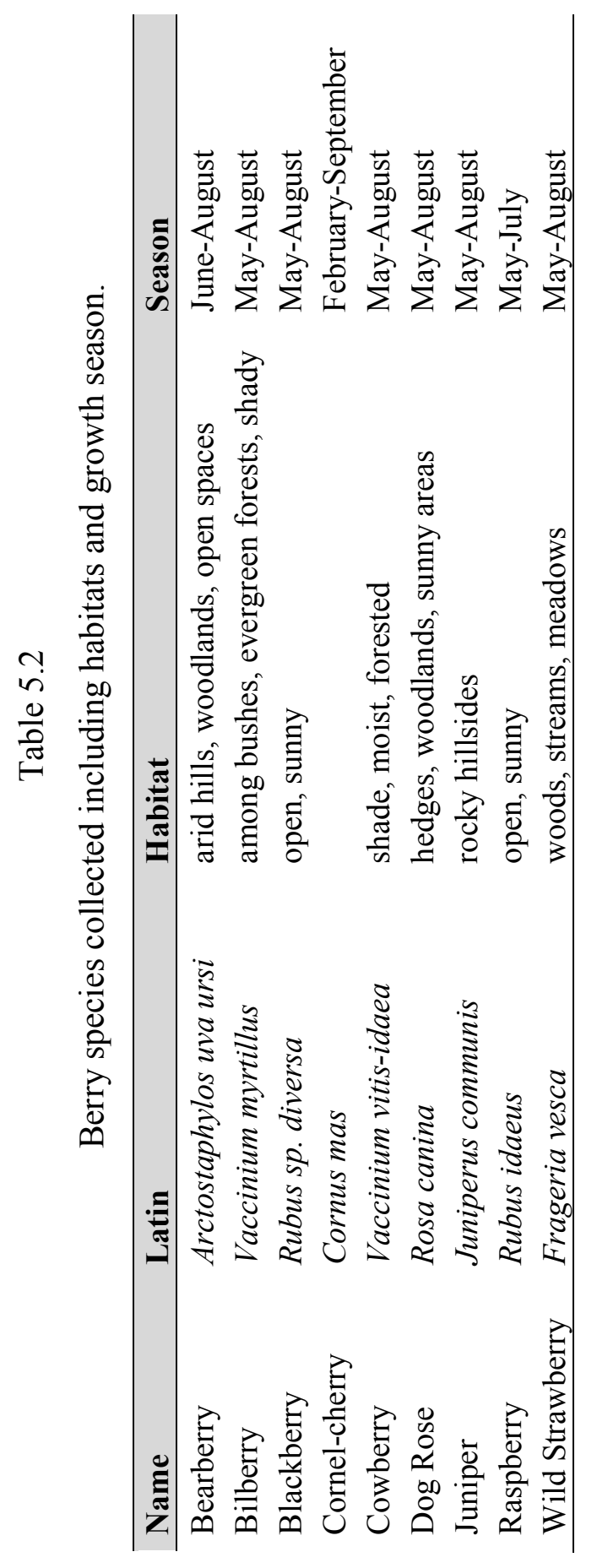


Herbs

Herbs were collected for their medicinal attributes and were mentioned by 64 percent of the participants interviewed. Saint John's Wort is the most frequently collected herb, followed by wild thyme, oregano, and peppermint (Table 5.3). Informants stated that when they are sick, they know exactly where to find which herb they need. The most common uses of the herbs are for coughs, colds, kidney and bladder infections, diabetes, hypertension, and depression (Table 5.3).

The herbs can be found in the same location each year (Table 5.4). All but two of them are located in dry, open, sunny areas such as meadows, grasslands, and hillsides. The herbs were the only product of all the NTFPs that the amount found in the forest has not changed in the past 20 years. The price of herbs also has not changed. If sold at the market, they are worth 50 stotinki, half a lev, for a small bunch. The participant interviewed with a selling stand at the local market was the only person who sold herbs, and she indicated that it was not for an income that she sold them, but rather as a hobby as she is retired.

The herbs are collected starting in early spring through early fall. One person stated, "I collect when the sun is shining because the herbs have a better aroma and I don't collect a day after it has rained." Another Muslim stated:

"There is a holiday in June, called Enyovden, which is a Christian holiday, but we participate as well. On this day we wake up before the sunrise and bathe in dew. Many people say this is the best day to start collecting herbs. They must be collected before there is any dew on them and they can't be wet from rain. Then the herbs must be dried in the shade."

All of the herbs are dried for use in teas, but sometimes may be used fresh. Figures 5.4 through 5.11 are pictures of the most commonly used herbs, shown dried for tea. 


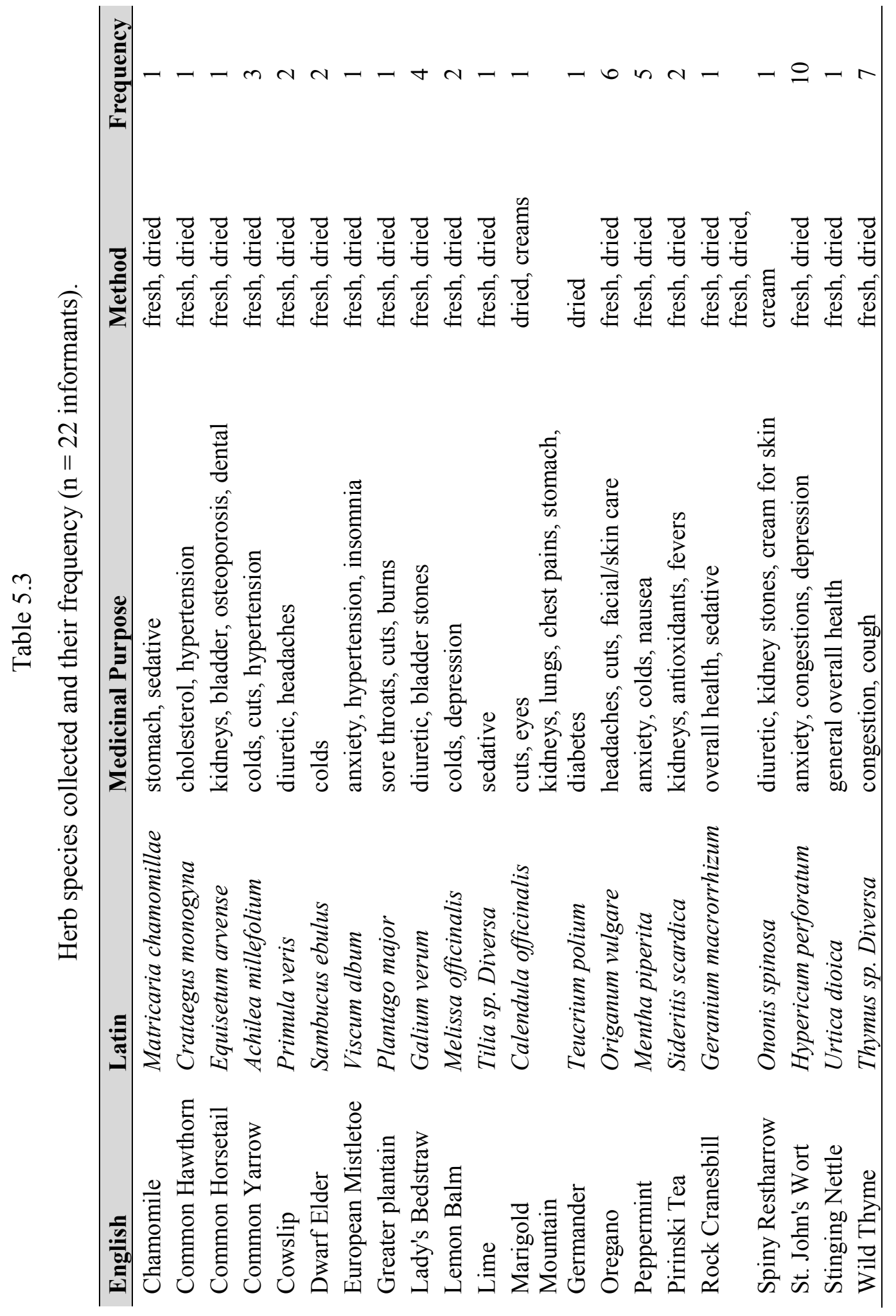




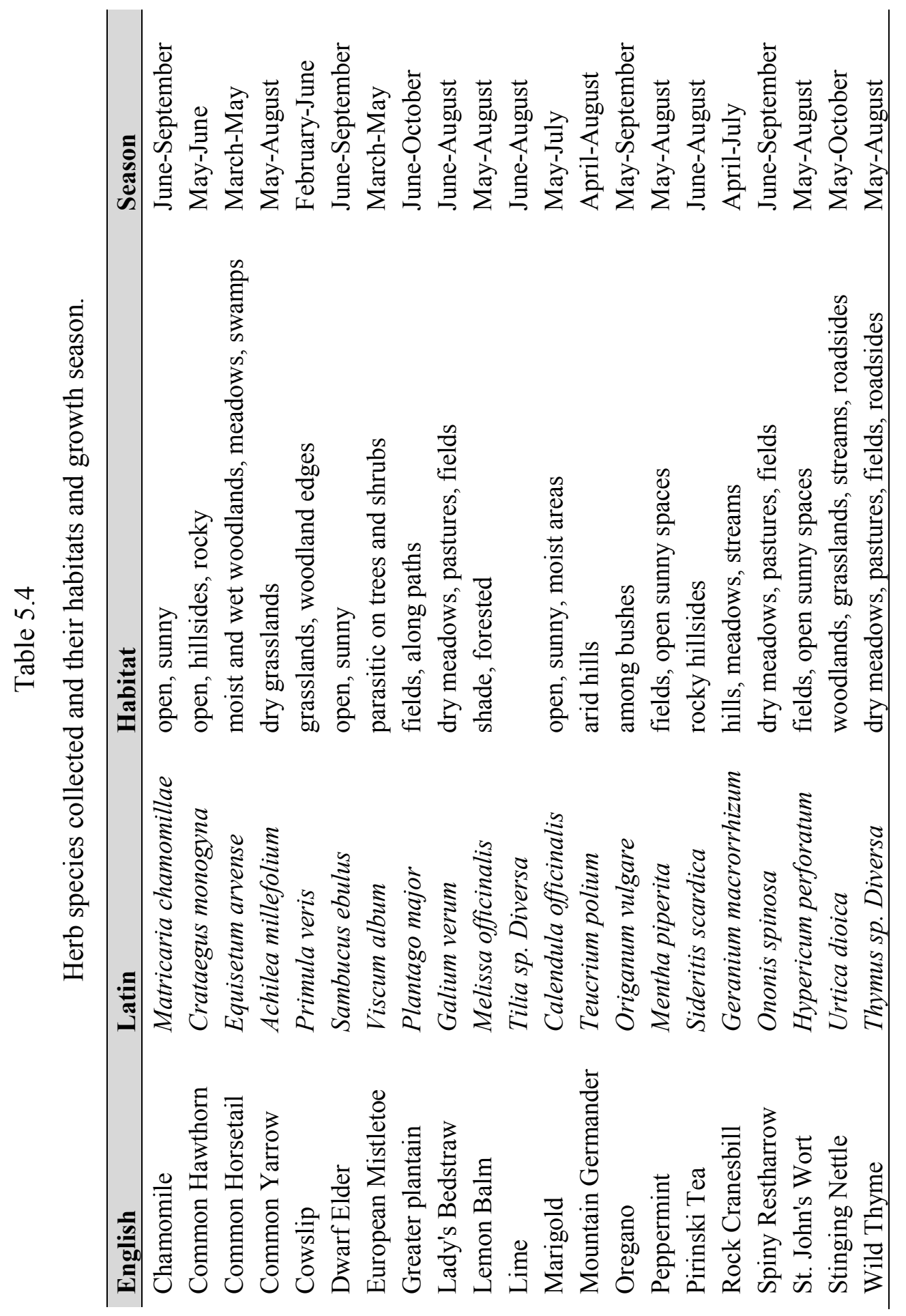



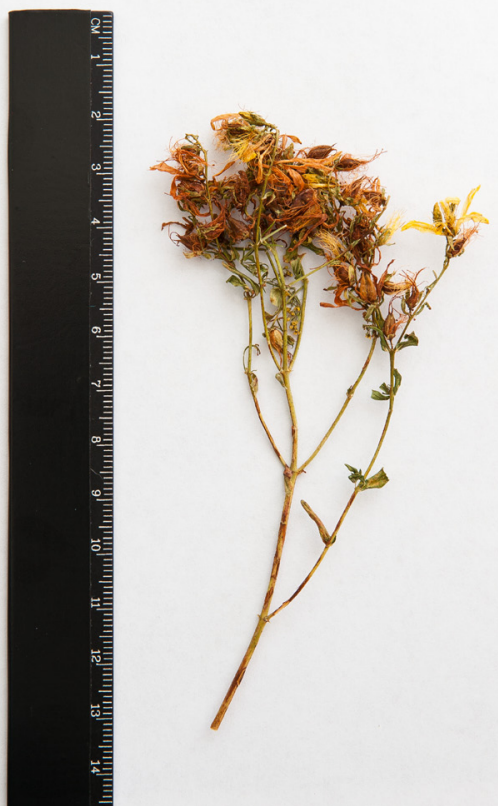

Figure 5.4: St. John's Wort

Photo: Andy Bertsch (See Appendix A)
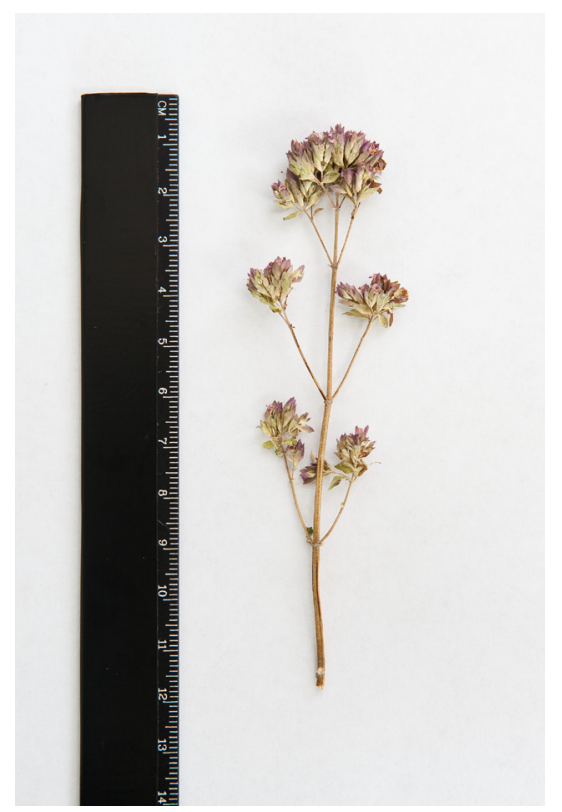

Figure 5.5: Oregano

Photo: Andy Bertsch 
Figure 5.6: Wild Thyme

Photo: Andy Bertsch
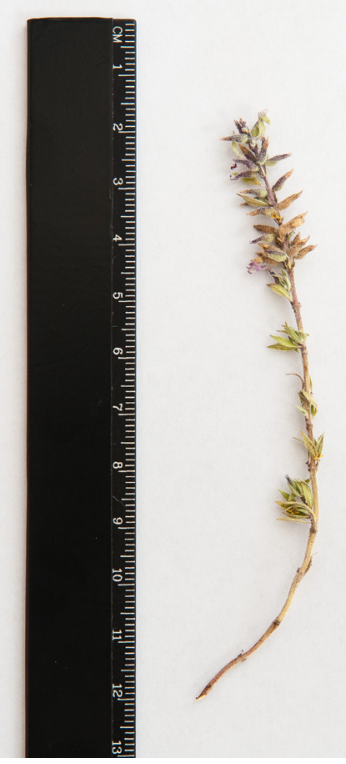

Figure 5.7: Peppermint
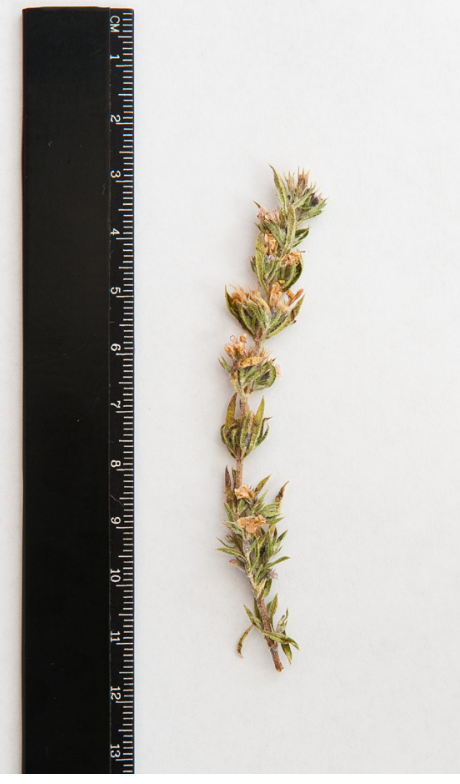

Photo: Andy Bertsch 


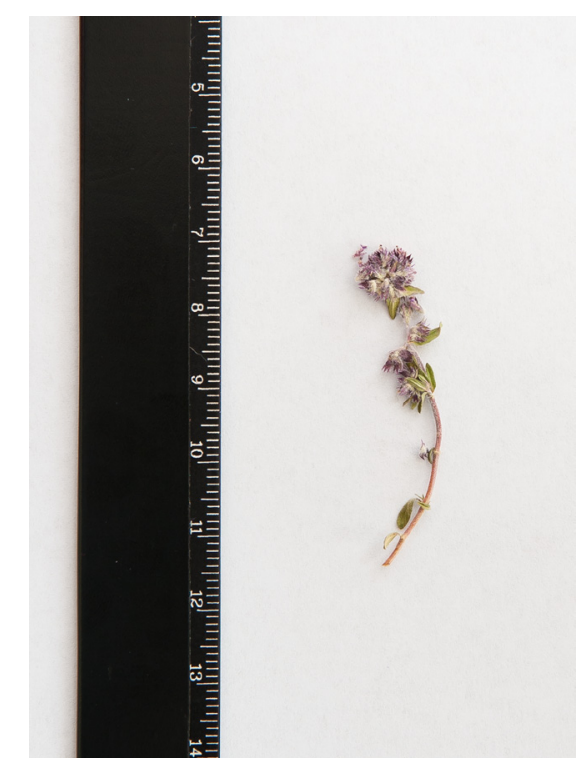

Figure 5.8: Lemon Balm

Photo: Andy Bertsch

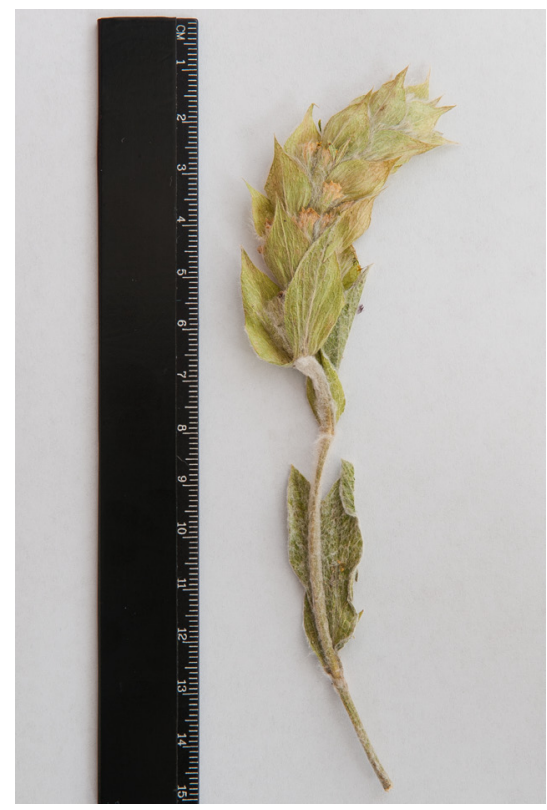

Figure 5.9: Pirinski Chai Photo: Andy Bertsch 


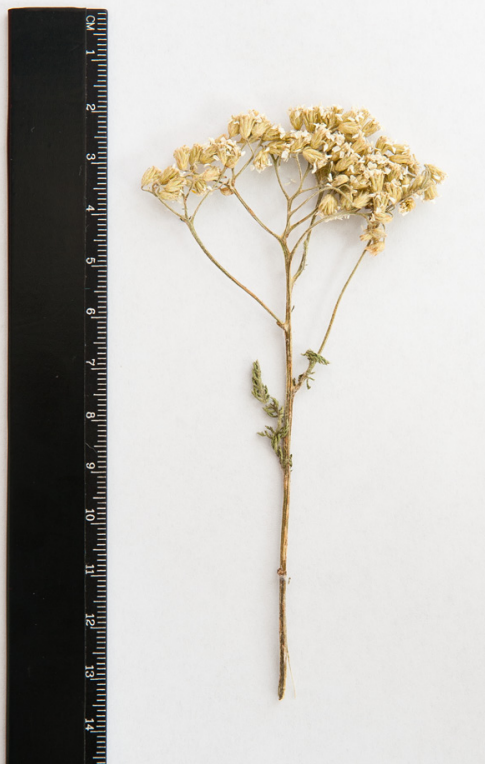

Figure 5.10: Common Yarrow

Photo: Andy Bertsch

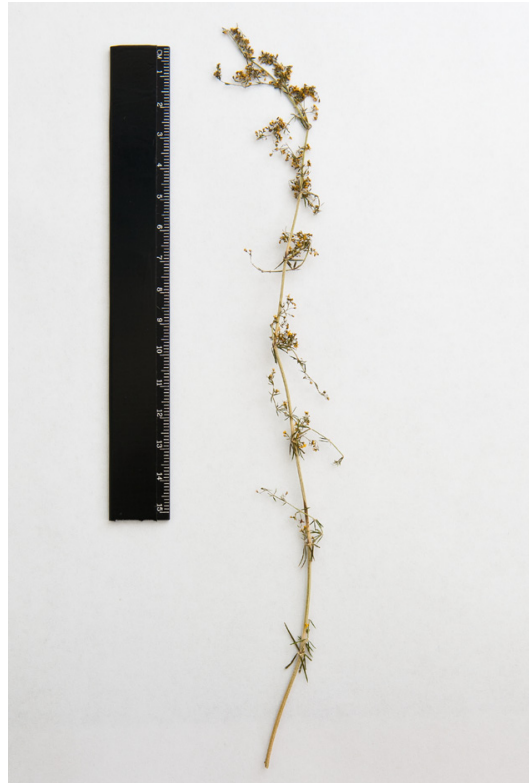

Figure 5.11: Lady's Bedstraw

Photo: Andy Bertsch 


\section{Mushrooms}

Mushrooms are the most frequently collected NTFP. Eighty-six percent of the people interviewed collect them, but those who rely on them as a source of income have a greater knowledge of them and also collect a wider variety. All ethnicities collect manatarka (Boletus) and patchikrak (chanterelle), the rest of the species listed in Table 5.5 were mentioned by the Roma participants (Figures 5.12 and 5.13). All of the mushrooms listed in Table 5.5 are sold to the market.

The manatarka and patchikrak have the highest frequencies of collection because all ethnicities collect them, are commonly found in the forest, and have the highest prices at the market. The other species listed may all be sold to the market and only those participants whose main source of income comes from mushrooms search for them in the forest. These species were all listed by the Roma people.

The smruchkula (morel) is worth the most, but least commonly found in the forest because it grows best after fire disturbances. Manatarka and patchikrak are commonly found in the forest and their relatively high prices help drive collection for markets. Manatarka are 12 leva per kilogram in the beginning of the season and will go as low as five or six leva per kilogram at the end of the collecting season. The patchikrak are usually four leva per kilogram, except during 2010 when they were one lev per kilogram.

A person who collects mushrooms with the goal of selling them to the market may average 15 kilograms a day. A young male Roma collector stated, "I have collected mushrooms for an income since I was 16, in an average day I can collect 25-35 kilograms." Mushrooms require moist habitats for growth and are often associated with a specific ecosystem. The Roma collectors identified specific species of trees and types of forests associated with each mushroom species.

All of the mushrooms are collected during the rainy season in the spring and fall. They will also appear during the summer months one to two weeks after a heavy rainfall. The growing season and habitats of each of the mushrooms is shown in Table 5.6. Mushrooms are the most economically profitable NTFP in the forest and therefore sought the most frequently, especially in economic downturns. They are also the most 
dependent on specific ecosystems; disturbances in these ecosystems have the ability to affect people who depend on them for their livelihood.

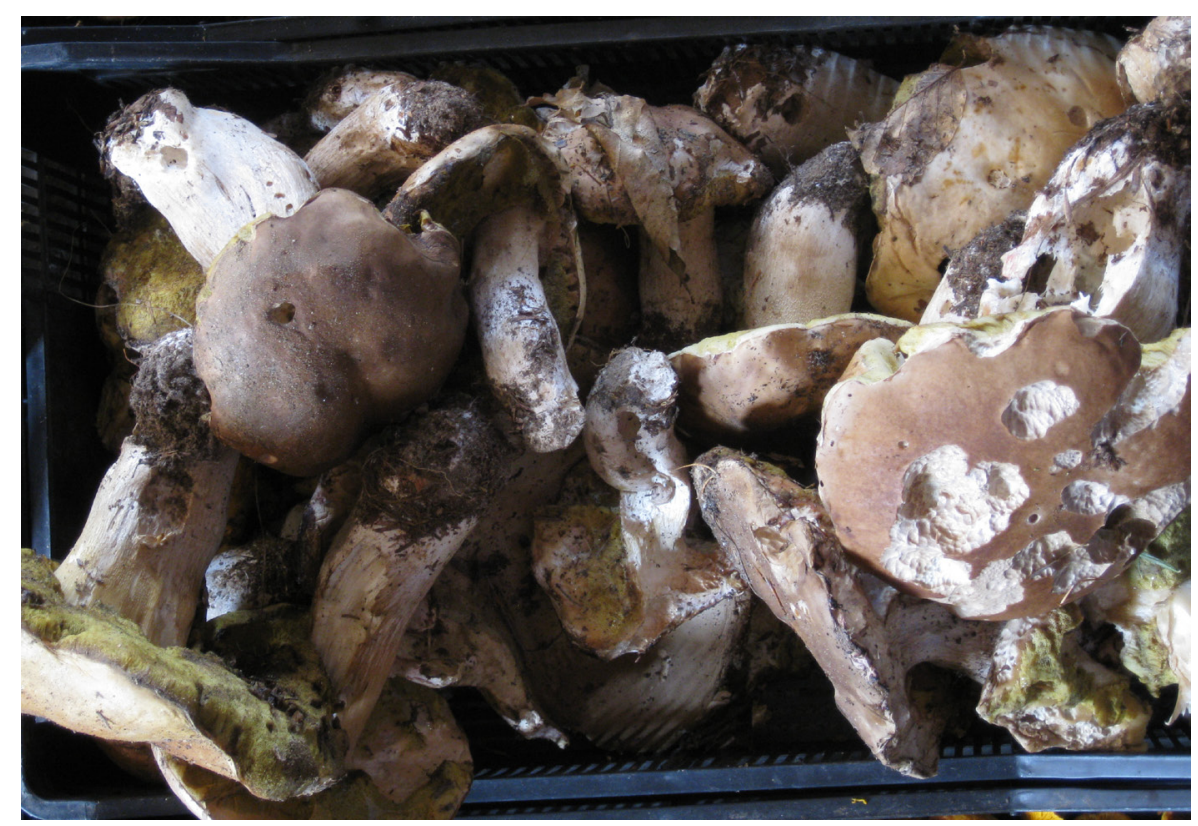

Figure 5.12: Manatarka at the buying station in Rakitovo.

Photo: Callie Bertsch

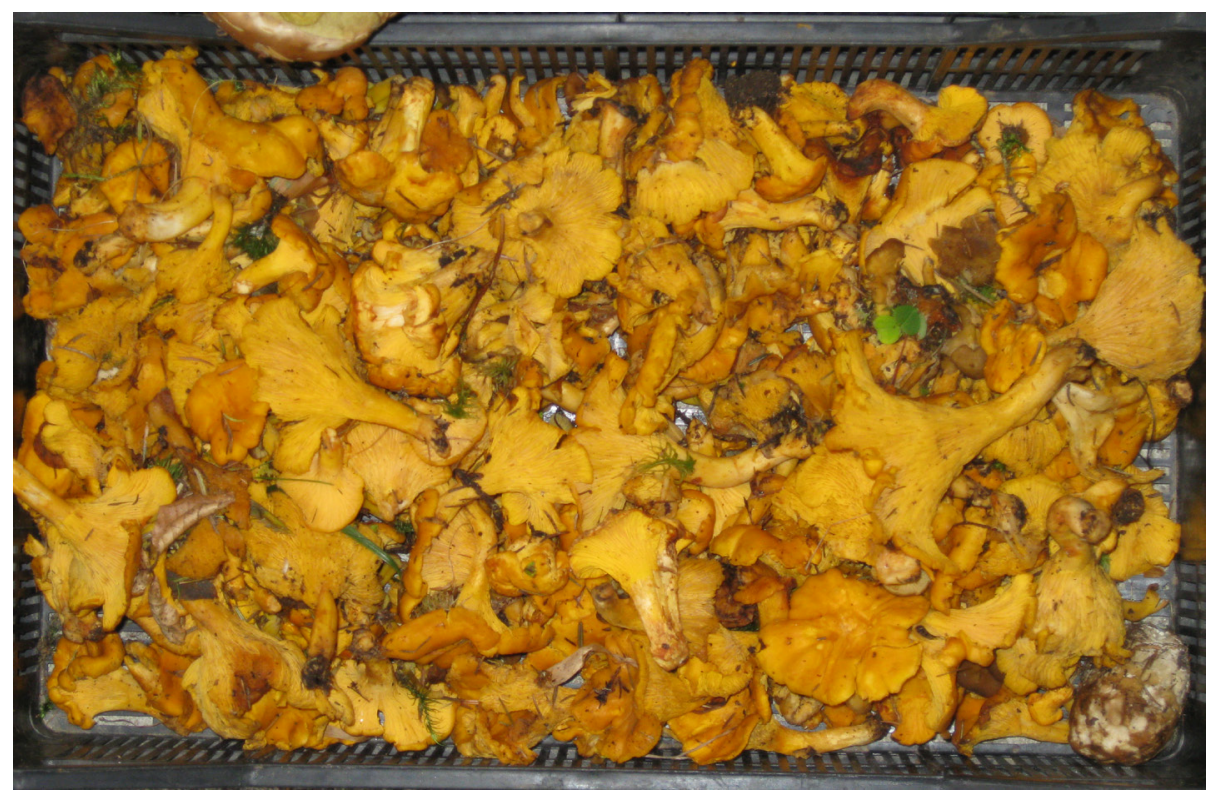

Figure 5.13: Patchikrak at the buying station in Rakitovo.

Photo: Callie Bertsch 


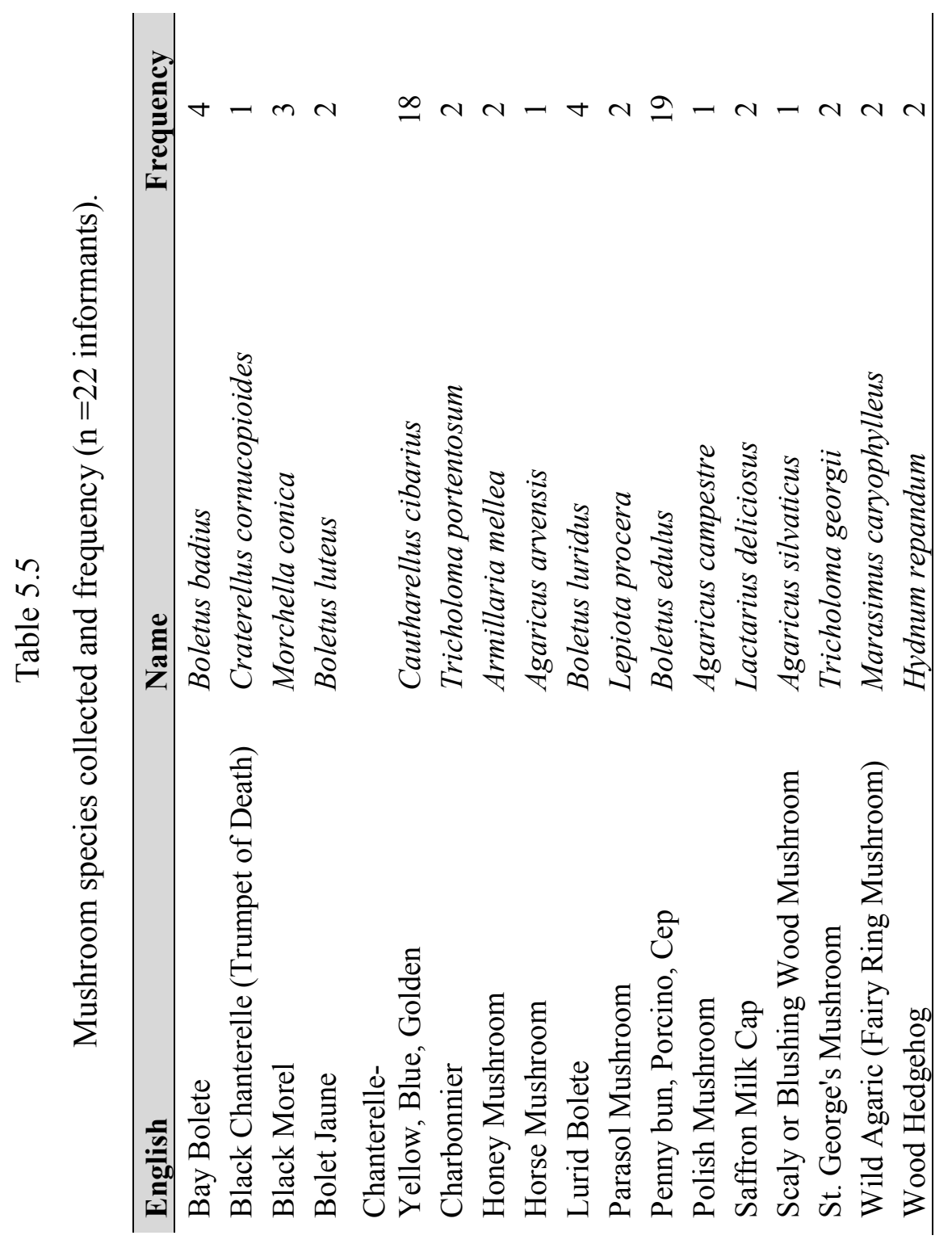




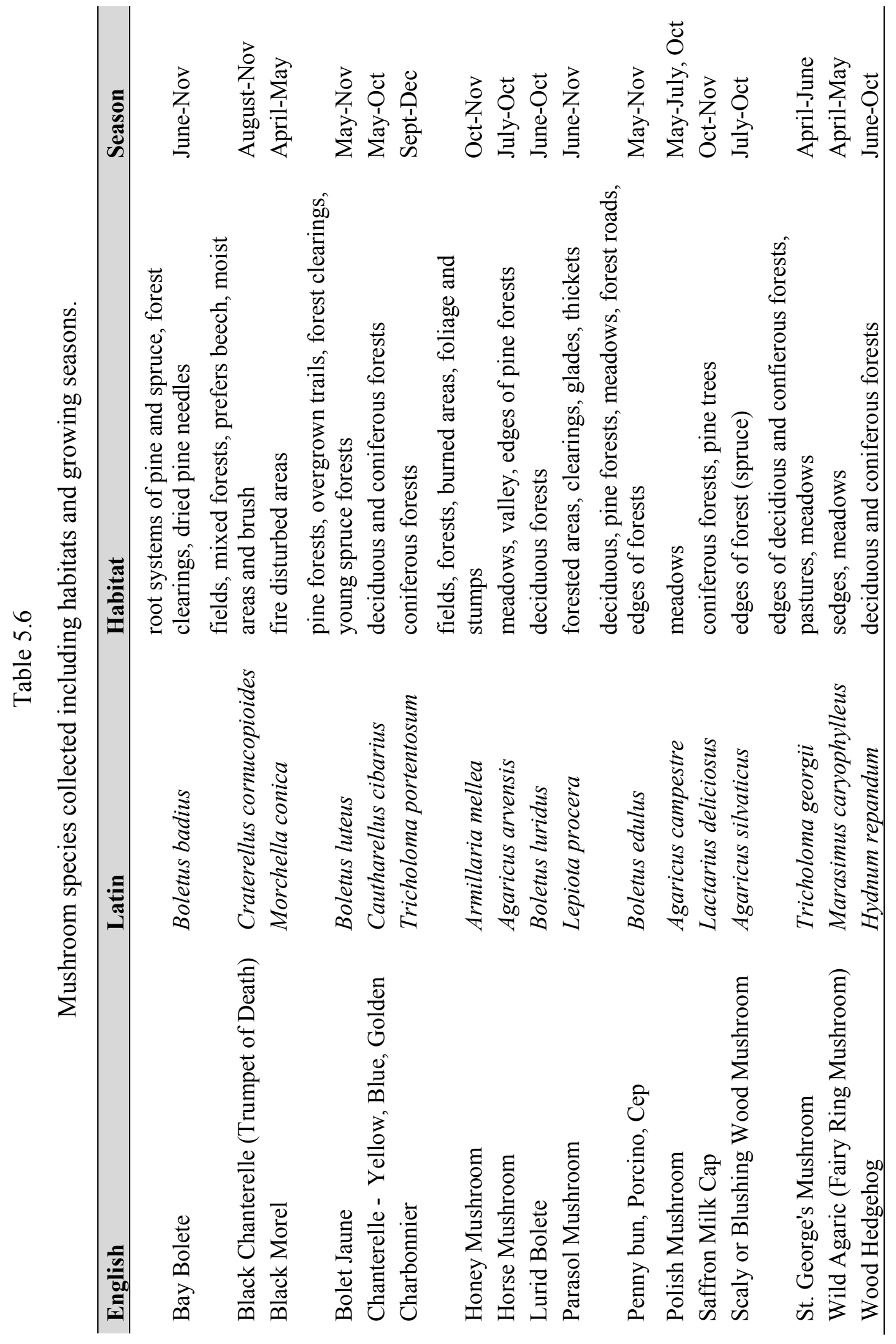




\section{Changes in the past 20 years}

An important aspect of the study was to gauge the perceptions of the informants in regards to changes in the supply of NTFPs in the forest, economic changes that have occurred in the market prices, and how the forest ecosystem has changed. When the NTFPs are divided into groups of berries, herbs, and mushrooms, there are clear differences in the changes of these products in the last 20 years. Mushrooms have changed the most, followed by berries, and lastly the herbs.

The people who collected mushrooms to be sold to the market all indicated that within the past few years, mushrooms have become difficult to find. Some people said the lack of mushrooms was a tragedy and among many of the Roma people it was indicated that the level of mushrooms was so low, they will not have money to buy bread or be able to heat their homes during the winter. An older Roma woman explained:

“There are no mushrooms in the forest. We haven't earned any money. We can't afford to buy bread. I've had four operations on my head and I have to pay medical bills, I'm expecting my eleventh grandchild, and we have no money because there are no mushrooms."

Another informant who was a government employee during communism and had worked closely with the forestry department stated:

"When I worked for the forestry department 20 years ago, we cut 20,000 cubic meters out of the forests here in Garmen, now they take 110,000 cubic meters. They are clear cutting the forests and there are no mushrooms because of it."

Less than nine percent indicated that there has not been a change in the quantity of available resources in the forest. Of these, half were Bulgarian and only used the forest for herbs, the plant group where the quantity has changed the least. Twenty-three percent reported seeing a decrease in specific herbs such as Pirinski chai and St. John's Wort. Four reasons were given for the decrease in NTFPs. 
Change in the forest ecosystem was listed the most frequently, by 59 percent of the respondents, as the reason for fewer NTFPs. Seventy-seven percent of the people who listed this as a reason were referencing mushrooms. Herbs were only listed by less than eight percent as being affected by changes in their ecosystem. Berries that are associated with forests such as bilberry and cowberry were affected most of all berry types.

The habitats of some mushrooms require growth next to another plant such as a specific type of tree. When these trees are clear cut from the forest, the mushrooms disappear. All of the Roma interviewed stated that they must travel farther to find mushrooms when the forests where they typically collect have been cut. In contrast to this, some people spoke of the morel mushroom that thrives after fire disturbances. A Roma woman stated:

"There was a plane crash near the city of Blagoevgrad which started a forest fire. A few months after the fire the smruchkula started growing everywhere where the fire had been, and we've been going there ever since to collect."

Blagoevgrad is nearly an hour and a half from her village, yet she is willing to travel there because the smruchkula is relatively profitable.

Improper collection method was listed as the second reason by 54.5 percent of the informants. Three-fourths were referring to herbs and berries such as bearberry, cowberry, and bilberry which are profitable at the market. People collect using mechanized methods in the form of a small, hand-held metal device that aids in berry removal, but also damages the leaves and branches of the plant reducing production in subsequent years. Participants also stated that people collect herbs by removing the plant at the root, though faster and easier, this leads to a decline in the plant population.

A notable herb is what the local people call Pirinski chai. Observations of the participants and other Bulgarians indicated that this herb is of cultural importance because it is native to Bulgaria and is valued for its medicinal properties and pleasing aroma. It grows on rocky hillsides in the mountains and during the year 2010, the 
Bulgarians said they did not see it at all. It is listed as endangered because of market demand. Informants stated that people collect it at the root for faster collection. The high market demand and decreased availability of the product in the forest has led to a growing business of cultivation of Pirinski chai.

A portion of the people commented that people collect mushrooms improperly by not cutting the stem with a knife. However, this is a misconception and not the cause of the disappearance of mushrooms. Wholesalers only accept mushrooms that have the entire stem because they will stay fresh longer. The Roma people interviewed all said that they collect with the entire stem because that is the only way the buyers accept them.

The increase in the number of people who collect NTFPs to supplement their income was listed as the third reason. In 2009 and 2010, the global economic crisis was prevalent in Bulgaria. People who were living and working in other countries were forced to come back to Bulgaria because they had no work. Many people stated that, "...everyone collects mushrooms now in order to buy bread."

Mushrooms have been affected most by this because they are the most valuable. Forty-one percent gave this as a reason for the decrease in products and over half of them were speaking specifically about mushrooms. Many participants said that they have been collecting since they were children, but because of the crisis, people who lost jobs have returned to collecting leading to an increase amount of "traffic" in the forest. This may be a temporary trend, if the economy improves.

Weather patterns were listed by 36.4 percent as the third reason. Dry years will lead to fewer mushrooms which require moist environments for growth. Many people noted that the summer of 2010 had been dry. Lack of rain during the growing season affects the mushrooms more than the herbs and berries.

Economically, it is difficult to measure the change in prices of NTFPs during the last 20 years because of inflation and differential price changes. In the early 1990s, the mushrooms were purchased for less than one lev, but the cost of living was lower. One person stated that now the mushrooms can be purchased for 12 leva, but that amount of money isn't enough to cover the cost of living. 
In the year 2010 each informant noticed a drastic change in the price of the mushrooms. An example is that of patchikrak mushrooms which have never dropped below four leva per kilogram. In 2010 the price dropped to one lev. Similar changes were seen with manatarka mushrooms. The former government employee with knowledge and experience working with the forestry department expained the situation:

"Last year, manatarka and patchikrak were purchased the most, their price was the best. This year, as there is a financial crisis, whatever they are doing, whether on purpose, they are simply playing with the people. Patchikrak always started at 12 leva, when the crop is low, and fell to six and never below four leva when the crop is abundant. For a hundred years, we all know the price, we live in a small village, we are bored, and we know everything about the forest. The price has never fallen below four leva. At the moment it is one lev. I assume that outside Bulgaria the price is 5 Euro and it's political. Yesterday I saw a woman who had collected 15 kilograms of patchikrak, three bags full. That's only 15 leva and she has two kids. She has to support them on 15 leva for one day. That's five leva per day per person. He who relies only on mushrooms for their income, it will be a difficult time. This year is just a tragedy for the people. The mushrooms have no worth. The wholesalers hide the price they sell them for. With inflation the price should at least be the same, if not more."

All of the Roma people as well as a small percentage of the Bulgarians and Muslims blamed the wholesalers. One young, male Roma said, "Every year there is a conflict with the wholesalers. There are only five or six of them and they agree on a price which isn't fair. It's always a conflict." The woman who ran the wholesale point said, "The market used to be better, but now there is a crisis. No one is buying throughout Europe." However, most of the participants were skeptical because there have been economic downturns in Bulgaria prior to the most recent global one which did not change the price of the mushrooms. 


\section{Problems among groups of people}

When specifically asked the question about problems existing between people in the forest, the answer was always the same: "We're all just trying to live, we share the forest, there are no problems, and whoever gets to the products first, gets them." However, there are underlying conflicts between different ethnicities. One Muslim commented on the Roma people who caravan in large groups, destroy the vegetation where they camp, make it difficult for others to collect in the same area, and do not clean up after themselves.

The most crucial conflict was between the people who sell their products and the buyers at the stations, especially when the sellers are Roma and the buyers are Bulgarian. One hundred percent of the Roma interviewed believe that the wholesalers treat them unfairly. Their belief is that when their product is weighed the buyer rounds down on the weight resulting in a loss of money. In 2009, the buying station in Rakitovo, a village where the study was conducted, burned down. All of the Roma people said this was God punishing them for cheating the people.

Examples of outright discrimination against the Roma in Bulgaria exist. One Roma told the following story:

"One year I decided to collect mushrooms with a friend, who was Bulgarian. We camped in the forest and after a few days we took our mushrooms to the wholesaler. He told my friend what price he would give him per kilogram and then he told me a price that was two leva less. I asked why and he said it was because I was inexperienced, which he had no way of knowing."

In the region of the study, there are no Roma nationals who manage the wholesale stations. A more educated Roma who was interviewed said it would be a good idea for them to enter the process at this point to ensure fair prices for their people. It is important to note that the Roma are not the only people who are skeptical of the wholesalers. Bulgarian and Muslim ethnicities all mentioned that they have either experienced or heard of discrepancies at the stations. 


\section{Forest Management}

The most frequent answer given in regards to changes in the quantity of NTFPs was the change in the ecosystems where the mushrooms, herbs, and berries grow. Those who stated this said that the forest is changing because of substantial increases in timber harvests. The older Bulgarian and Muslim participants said that the forest has changed dramatically and that this change is a tragedy. The former government employee with experience working in the forestry department said that there is no longer control in the forest, "The people just watch as the forest disappears, not believing what they are seeing." He lives in an area where the trees are being cut and he said that the companies cutting the trees do so in a way that damages the forest.

The forestry service in Garmen actively manages the forests and the ruling political party has ultimate control over harvest levels which is ultimately controlled by council of ministers in charge of the state forestry agency (Bulgarian State Forestry Agency 2009). The belief is that the logging companies, forestry department, and the government are trying to get rich, without thinking about the resources they are damaging and people's lives they are affecting. The former government employee during communism stated:

"They are clear cutting the forest. There was once an abundance of mushrooms, now there is nothing. No trees. In Bulgaria they cut, in other countries you don't see it like this. And they cut poorly. The firms do this, in order to become rich, and the mushrooms have decreased greatly because of this."

During communism forest management was more controlled. Prior to 2009, the Turkish party in Bulgaria was given control of the forest, which most people indicated was a mistake. One Bulgarian stated:

"The political parties do not take care of the forests, even though they are given control of them. In 2009, the Turkish party was given control of the forests and 
they did nothing to help them because they do not care about Bulgaria's environment."

Bulgaria's long history with the Turkish people has created animosity, stereotypes, and distrust of the Turks.

The logging and timber industry employs approximately ten percent of the people living in the study area, which is the third largest sector after tailoring and education. An informant from the forestry department who has knowledge of management practices in Garmen was asked how strict the management practices were and his reply was that they are not strict at all. This is an outcome of employees who do not have a vested interest in preserving the ecosystems and opportunities for economic gain. Observations of Bulgarians in the rural regions for two years indicated the people are educated, but do not feel they are paid well enough to put energy into their work.

The informants all stated that the forestry department needs to control the forests in a multi-faceted way. An older Bulgarian woman said:

"The forestry department could better control the forests. They have specific regions, when they see something not done properly; they need to help manage it. There is television and radio to educate people; they used to do this in the past. It's important to educate the children and teenagers. No one is born educated. It will be very sad if these resources disappear because they are a source of medicine. For Bulgarians it is important to have these things. They are very useful."

Her belief is that the forestry service needs to start educating people again. Participants also said that the forestry department needs to control the timber companies and enforce the rules and regulations to create less damage in the forest when they are logging.

Non-timber forest products play a crucial role in the livelihoods of Bulgarians from a cultural, medicinal, and economic standpoint. One man stated that in previous years, a person could collect enough mushrooms to earn a living for an entire year. It is 
plausible that a mushroom collector could earn half a month's average salary from a day's worth of work; therefore, making it possible for the income they earn throughout the season to last the entire year when combined with state welfare. Furthermore, all of the Muslims stated that everyone in the villages in the mountains collect and have knowledge of NTFPs. One Muslim man stated, "In this village there is not a house that doesn't collect forest fruits, mushrooms, herbs, and teas. We depend on the balkan (mountains)."

Two Bulgarians stated that the forests are their pharmacy. One-hundred percent said that they are able to save money by collecting herbs and berries and not spending it on prescription drugs or for food at the market. However, they were unable to give an exact amount of money that the NTFPs replace for their food and medicine. The cultural role that the NTFPs play in their lives was emphasized. One man called the forest his garden because he knows exactly where the things he wants and needs are located.

The Roma people collect for the purpose of income generation, if the economy in Bulgaria were to improve, it is unsure if the Roma would enter into low paying manual labor or continue to collect NTFPs. The collection of mushrooms and profitable berries may become an elite job among the Roma or Bulgarians who are able to make a business of collecting large amounts of the product. Cultivation of mushrooms may become an important enterprise.

All of the species are dependent on specific ecosystems that if changed will affect the quantity of the NTFPs available. The collection methods also affect the re-growth each season. In the current economy, it is important for the people to be educated in the proper collection methods as well as a system of forest management which manages for the whole ecosystem and not just the trees.

The people in this study area are a small representation of the people who live in rural, mountainous regions of Bulgaria. They also represent the larger group of people and cultures that rely on the forest ecosystem for an income, diet supplementation, and medicinal remedies. While the number of participants was limited at 22, their consistent responses among ethnic groups combined with participant observations over two years indicate that their collection habits and opinions are accurate and validate this study. The next chapter will discuss how the results of this study fit into the wider spectrum of forest 
management for NTFPs to preserve the economic and cultural livelihoods of the people. 


\section{Chapter Six: Conclusion}

The local people living in rural villages in the southwestern Rhodope Mountains have an economic and cultural reliance on NTFPs. Their traditional ecological knowledge (TEK) of the forests, including where NTFPs are located, their medicinal purposes, and the ecological disturbances that impact the products indicates a need for the management of the forests that accounts for the local people and their use of them.

The inhabitants of the Rhodope Mountains are well-known in Bulgaria for the creation of a sub-culture that have evolved with the Muslim villages in this region. Traditionally, the people do not dress as typical Bulgarians and do not belong to the dominant religion, resulting in discrimination. Because of this, the people have unified and have done so through their ties to the land. Therefore, their knowledge, observations, and experiences must be considered when managing the ecosystems.

Similar studies have been completed in Bulgaria that echoes this statement. One study was an ethno-botanical survey of the types of herbs collected throughout Bulgaria and their uses. The study was broader in a geographic sense and also focused specifically on herbs and their uses. The surveys provided a list of 128 herbs found in Bulgaria, and people identified which of those herbs they had collected. Participants were also asked to answer a set of five questions regarding which herbs have become more expensive in the past ten years, which herbs have become more difficult to find in the environment in the past ten years, herbs that were previously used that can no longer be found, percentage of income which comes from selling herbs, and whether the abundance of Bulgaria's herbs are threatened (Ploetz 2004).

The focus of the study in this paper was to gauge the economic and cultural importance of not only herbs, but also berries and mushrooms among the three ethnicities that exist in Bulgaria. In Ploetz's study, the results were similar for the value that people placed on herbs for the cultural and medicinal purposes. Participants also gave the same responses in relation to changes in the forest ecosystem resulting in changes in the availability of herbs. The opinions of respondents were also similar in both studies. Many of the causes listed for the reasons that there are fewer herbs in the forests were 
because of lack of knowledge of proper collection habits and that the forests are becoming polluted and the trees are cut down (Ploetz 2004).

Ploetz's study also looked at the geographical differences in herb collection and use within Bulgaria. Her study confirms that the region of the Rhodope Mountains has higher collection and use of a wider variety of herbs than the rest of Bulgaria. This is attributed to the relief and climate of the Rhodope Mountain region which is rolling hills and part of a warmer Mediterranean weather pattern (Ploetz 2004).

This study and Ploetz's have similar findings regarding the use of herbs in the home for medicine and food and which herbs are used most. However, this study found that while herbs are important culturally, there are other NTFPs that are collected which have a higher economic impact on the livelihood of people living in the southwest Rhodope Mountain region. Mushrooms and berries are relied on for supplemental income and to replace food products they would otherwise purchase at the market. Ploetz's study did not identify the ethnicity of its participants. This is an important factor of this study in regards to knowing how to manage the forests to benefit the people living in the study region.

The findings of both of these studies indicate the importance of managing the forests in a way that accounts for the cultural and economic uses for the local people, not just the economic goals of the forestry departments, logging companies, and ultimately, the government. The forestry department has recognized this in a declaration composed by representatives from the municipalities located in the Rhodope Mountain region. The declaration is titled "The significance of nature as a resource for sustainable development of the western Rhodope region (Bogdanov and Stiptsov 2007).” The following statements are the basis of the declaration:

1. Nature is the most important resource which is found extensively and in variety throughout the Rhodope region.

2. Nature is an inseparable part of the livelihoods of local communities, provider of food, water, and other life necessities. 
3. Nature is a key element for sustainable local development and as such should be reasonably, accountably, and effectively utilized.

4. Nature resources provide opportunities for achieving higher living standards and local prosperity through development of regional economic sectors such as forestry, agriculture, tourism, etc.

5. Local and regional economic development should and must coincide with maintaining natural heritage through integration of nature conservation issues into the planning process.

6. Traditional human activities are an integrated part of the natural and cultural landscape of the Rhodope Mountains and should be performed in naturefriendly ways, preserving biodiversity.

7. Certain human activities have a negative impact on nature and raising environmental awareness is a guarantee for clean environment.

8. The natural environment will be inherited by future generations and the foundations for its sustainable use must be set.

9. Environmental education of young people is the first step to responsible attitude towards nature.

10. Territorial planning is of prime importance for the full utilization, conservation, and regeneration of the natural resources.

11. Nature conservation must be a leading priority in the present and future strategies without excluding local potential for economic development.

12. The municipal and regional planning process has to ensure the balance between nature conservation and the necessity for resolving economic and social concerns in the region.

The local forestry department leaders have recognized a need for the management of the forests on a local and cultural level. However, enforcing these guidelines is difficult because it is easier to see the immediate economic gains of a timber sale over the long-term changes and effects in the livelihoods of the local people. 
In 2001, a study was completed in a small, Rhodope Mountain village that compared the perspectives of the local people who rely on the forests for NTFPs and agricultural purposes with the government's view of forests as 'harvestable timber' (Cellarius 2001). The findings were the same; the government and the local people have different priorities in regard to the forests. Both priorities are important in relation to the development of Bulgaria and must be considered in forest management planning.

This study was completed during a time of a global economic crisis. One of the reasons for the decline in mushroom abundance was because more people are forced to collect them in order to have money for necessities; bread was frequently mentioned. The market prices were the lowest anyone could remember. Fluctuations in the market have been shown to have an impact on NTFPs in the forest ecosystem (Arnold and Perez 2001). Often, when there is a market for a specific product, it is followed by a decline of the product in the natural forest ecosystem leading to cultivation by a group of elite members of a society (Arnold and Perez 2001). This was the case of Pirinski chai in the Rhodope Mountains.

Mushrooms may not disappear from the forest as a result of forest type conversion because of their growing cycles, but an economic downturn results in more people collecting mushrooms. This, combined with the over harvesting of the forests that the mushrooms are found in, contributes to a smaller profit for the individual who relies on it as a main source of income during specific parts of the year. The failure to manage forests with NTFPs as a primary goal is felt more during times of economic hardship by the local people.

The people living in the southwestern Rhodope Mountains have an attachment to the land both culturally and economically. A change in their forest ecosystem not only changes the landscape of the land, but may eventually change the landscape of their culture. The forestry departments and government need to realize the effects that current management practices have on the proud and culturally rich people of their country, as well as the economic impact it has on Bulgaria's marginalized minorities. 


\section{Reference List}

Arnold JEM, Perez MR. 2001. Can non-timber forest products match tropical forest conservation and development obejectives? Ecological Economics. 39:437-447.

Berkes F, Colding J, Folke C. 2000. Rediscovery of traditional ecological knowledge as adaptive management. Ecological Applications. 10(5):1251-1262.

Bernard HR. 2002. Research Methods in Anthropology: Qualitative and Quantitative Approaches. Walnut Creek (CA): AltaMira Press.

BG MOEW [Bulgarian Ministry of Environment and Water]. 2011. Ministry of Environment and Water of Bulgaria: Priorities; [updated 2008 Dec 17, cited 2011 March 4, 2011] Available from: http://www.moew.government.bg/index_e.html

Bogdanov KM, Stiptsov VH. 2007. Ustoichivo Socialno-Ekonomichesko Razvitie na Obshtina Garmen na Baza Gori i Gorski Recyrsi. [Sustainable Socio-Economic Development of the Municipality of Garmen Based on Forests and Forest Resources.] Sofia (BG): RYTA.

Bulgarian Ministry of Agriculture and Forestry. 2004. Environmental Assessment of the Forest Development Project, Bulgaria. Report: Helsinki.

Bulgarian State Forestry Agency. 2009. Timber Market Statement.

Cellarius BA. 2001. Seeing the forest for the trees: Local-level resource use and forest restitution in postsocialist Bulgaria. GeoJournal. 54:599-606. 
CIA [Central Intelligence Agency]. 2011. The World Factbook: Bulgaria; [updated 2011 March 16, cited 2011 Feb 23]. Available from:

https://www.cia.gov/library/publications/the-world-factbook/geos/bu.html

Crampton RJ. 2005. A Concise History of Bulgaria. $2^{\text {nd }}$ ed. Cambridge (UK): Cambridge University Press.

Creed GW. 1998. Domesticating Revolution. University Park (PA): The Pennsylvania State University.

European Commission. 2003. Eurostat: Unemployment rates. [updated 2010 Dec 6, cited 2011 March 7]. Available from:

http://epp.eurostat.ec.europa.eu/portal/page/portal/employment_unemployment_lfs/introd uction

European Commission. 2003. Sustainable Forestry and the European Union. Luxembourg: European Communities.

Guest G, Bunce A, Johnson L. 2006. How many interviews are enough?: An experiment with data saturation and variability. Field Methods. 18:59-82.

LaDuke W. 1994. Traditional ecological knowledge and environmental futures. Colorado Journal of International Environmental Law and Policy. 5:127-148.

Municipality of Garmen. 2006. Municipal website: population and economic information; [updated 2006 June, cited 2011 Feb 24]. Available from: http://bulgaria.domino.bg/garmen/ 
Municipality of Garmen. 2010a. Official website of the Municipality of Garmen; [updated 2011 March 23, cited 2011 Feb 24]. Available from:

http://www.garmen.bg/new/home

Municipality of Garmen. 2010b. Municipality of Garmen: Livelihoods, Nature, CulturalHistorical Heritage; [updated 2010 March 22, cited 2011 Feb 24]. Available from: http://www.garmen-travel.org/index_en.html

Ploetz K, Orr B. 2004. Wild Herb Use in Bulgaria. Economic Botany. 58(2):231-241.

Puncheva A, Panova M, eds. 2002. Our Bulgaria. Popova K, trans. Sofia(BG): European Initiatives Foundation.

Szelenyi I. 2001. "Poverty under post-communist capitalism - the effects of class and ethnicity in a cross-national comparison." Paper presented at workshop "Culture and Poverty”, Budapest (HU): Central Euopean Univeristy, November 30 - December 2.

Transparency International. 2010. Corruption Perceptions Index: 2010 Results; [updated 2010, cited 2011 March 20]. Available from:

http://www.transparency.org/policy_research/surveys_indices/cpi/2010

UNEP/GRID-Arendal, Philippe Rekacewicz [Internet]. 1998. Environmental Knowledge for Change: United Nations Development Programme. [updated 2010, cited 2011 February 22]. Available from: http://maps.grida.no/go/graphic/bulgaria_topographicmap

United Nations Development Program. 2006. Strategic Plan for Sustainable Development of Agriculture, Forestry, and Tourism: Municipality of Garmen. Sofia (BG): PRMAC Alphamarket. 
United States Census Bureau (International Data Base). 2006. Data access: Bulgaria; [updated 2011 Feb 23, cited 2011 March 25]. Available from:

http://www.census.gov/ipc/www/idb/informationGateway.php

U. S. State Department [Internet]. 2010. Background Note: Bulgaria; [updated 2010 Sept 20, cited 2011 Feb 23]. Available from:

http://www.state.gov/r/pa/ei/bgn/3236.htm\#history

United States Peace Corps. 2008. Peace Corps Bulgaria training manual.

Vassilev, R. 2004. The Roma of Bulgaria: A Pariah Minority. The Global Review of Ethnopolitics. 3(2):40-51.

WHO [World Health Organization]. 2010/2011. Biennial collaborative agreement between the Ministry of Health of the Republic of Bulgaria and the regional office for Europe of the World Health Organization.

x-rates.com. 2011. Bulgarian -USD exchange rates; [upated 2011 March 27, cited 2011 March 20]. Available from: www.x-rates.com

Zimmerman EM. 2005. Valuing traditional ecological knowledge: incorporating the experiences of indigenous people into global climate change policies. New York University Environmental Law Journal. 13:803-847. 


\section{Appendix A}

\section{Copyright Permissions}

\section{Figure 2.1: Katie Leu}

From: Katie Leu (ktluwho@hotmail.com)

Sent: Mon 3/28/11 12:35 AM

To: calexber@hotmail.com

Hi Callie,

I give you my permission to use my picture. Good luck with your paper! and it makes me happy my name will be in your paper!

Katie Leu

Peace Corps Volunteer

Garmen, Bulgaria

+3590883450588

Кейти Лу

Доброволка от Корпус на Мира

Гърмен, България

0883450588 


\section{Figure 2.4: UNEP/GRID-Arendal}

Sources Unknown Cartographer/

Designer Philippe Rekacewicz, UNEP/GRID-Arendal Appears in Topographic maps

Published 1998 Feedback/Comment/Inquiry Feedback form Search for other graphics

With related subjects

Covering the same geographic area Use constraints

Using the graphics and referring to them is encouraged, and please use them in presentations, web pages, newspapers, blogs and reports.

For any form of publication, please include this link:

http://maps.grida.no/go/graphic/bulgaria_topographic_map

Please give the cartographer/designer/author credit (in this case Philippe Rekacewicz, $U N E P / G R I D$-Arendal) and give full recognition to the data sources used in the graphic.

Feel free to feature links to this page, or other pages on this site, but please refrain from linking to the actual graphics files directly, if possible (i.e. inline linking).

Re-publishing the full resolution version of the graphics (high-quality png and pdf), unmodified, as digital files for download requires approval from UNEP/GRID-Arendal (use this form).

We do appreciate if you have the possibility to send us a copy of any printed publications featuring our graphics. See the UNEP/GRID-Arendal contact page for mailing address.

Accessed on 2.22.11 


\section{Figure 5.2: Deborah Bloom}

From: Deborah Bloom (deborahbloom@gmail.com)

Sent: Sun 3/13/11 1:06 AM

To: calexber@hotmail.com

here you go. and of course you can use them for whatever you need i leave for paris on friday, can't wait!

hope all is well for you....

Deborah Bloom

Peace Corps Volunteer

Bulgaria

Дебора Блум

Доброволка от Корпус на Мира

България

\section{Figures 5.3: Kay Hannahan}

From: K Hannahan (kayhannahan@gmail.com)

Sent: Mon 3/21/11 9:29 AM

To: callie bertsch (calexber@hotmail.com)

Callie Bertsch has the right to use any photographs of mine that she wishes to.

Kay Hannahan 
Figures 5.4, 5.5, 5.6, 5.7, 5.8, 5.9, 5.10, 5.11: Andy Bertsch

From: cbertsch@charter.net

Sent: Mon 3/28/11 10:07 AM

To: calexber@hotmail.com

To whom it may concern,

Callie Bertsch has my permission to use photographs of plant life that I have taken for her Masters Thesis. These photographs may be used in whole or in part.

Regards,

Andrew Bertsch

418 Frieburger Ave.

Antigo, WI 54409

(715) $623-424$ 


\section{Appendix B}

\section{Survey and Consent Form}

\section{RESEARCH CONSENT FORM}

In addition to my duties as a Peace Corps Volunteer, I am conducting research on herb use as part of my degree requirements at Michigan Technological University. I will be interviewing people over the next year while I am living in Garmen. I would like to ask you about the collection of herbs in the community.

* I may use what you tell me in my written report to my professors at my university. When I write my report for the university I will not identify you in the report except in photographs and then only with your consent (see below). All of the information collected will be stored at Michigan Technological University.

* There are no foreseeable risks involved in this research.

* I hope that this information can help protect the areas where herbs are currently collected.

* I will return a final copy of my research to the Garmen municipality.

* I will have some particular things I would like to talk about, but you may ask me questions and talk about things you think I should know about it, even if I don't ask. You are not required to talk to me or answer my questions. You may decide to answer some of the questions, but you may also decide there are some question that you would not like to answer. Even if you decide now to talk to me about this questionnaire, you may later ask me to stop asking you about it. When you ask me to stop, I will stop asking you questions. You decide if you want to talk to me about resources you use in the community. Nothing bad will happen to you or to me if you decide not to answer my questions about my study.

* The Michigan Tech Institutional Review Board (Michigan Tech-IRB) has reviewed my request to conduct this project. If you have any concerns about your rights in this study, please contact Ms. Joanne Polzien of the MICHIGAN TECH-IRB at 906/487-2902 or email jpolzien@mtu.edu.

* Questions about the research can be directed to Dr. Blair Orr at (906) 487-2291 or bdorr@mtu.edu

* Do you have any questions?

I agree to participate in this survey with the understanding that I will not be identified and that I may stop participating at any time. 
Signed:

Date:

Signed by researcher:

Date:

\section{Photograph Permission Form}

I would also like to have your permission to take your photograph. Do I have your permission to use your photograph with your name in my thesis or report?

I agree to allow the use of my photograph with a name.

Signed:

Date:

Signed by researcher: Date: 


\section{INTERVIEW QUESTIONS}

Village:

Ethnicity:

Age:

Gender:

Household size:

Occupation:

Main Source of Income:

Secondary Sources of Income:

1. What NTFRs do you collect throughout the year?

a. On a scale of 1-5 (with 5 most important) how important would you rate each of these NTFRs.

i. In what way is each of them important? (culturally, food, medicine, etc)

ii. How is each of them specifically used? (fresh, dried, canned)

2. During which months do you collect each of these?

3. Of each of these NTFR, which ones are the most valuable monetarily?

4. What prices do you receive from the market per kilogram of each herb?

a. How has this price changed over the last 20 years?

5. Of each of these NTFR, which are the most valuable for use in the home?

6. In what type of habitat are each NTFR found? (hillside, near streams, rocky areas, etc.)

7. Do you collect them in all of those habitats, or just in certain types? Which types?

8. Do specific NTFR's grow in the same habitats? (Can you rely on finding two specific NTFR's growing together?)

9. Are specific NTFR's found in the same place each year?

10. Are specific NTFR's found during the same time of the year each year?

11. What percentage of your income comes from the collection of NTFRs?

a. If you do not sell herbs what portion of your expenses does collecting NTFRs replace?

12. How many kilograms of each NTFR are you able to collect each season?

a. How has this amount changed over the past 20 years?

b. If the amount has changed, why do you think it has changed?

13. If you need to buy herbs from the market, which do you buy?

a. How has this changed in the last 20 years?

14. Has the availability of certain herbs declined or increased in the past 20 years?

a. If so, why do you think there has been a change?

15. Has there been a change in the habitats where you typically find your herbs in the last 20 years?

a. If so, why do you think the habitats are changing?

16. Do you do anything to encourage growth or increase the production of the NTFR's you collect? 
17. Do you specifically go out looking for NTFRs or is it a by-product of other activities in the forest?

a. Typically, how far from home do you go to find the NTFRs?

18. Is the land you harvest on state or private owned?

19. How do you arrive at harvest sites? (car, by foot, horse/donkey drawn wagon)

20. Do you collect by yourself or with other people? With whom?

21. Are there conflicts over the ability to harvest in a specific location? Describe (location, groups of people?) Are these new conflicts or have they happened for quite some time? 


\section{Survey and Consent Form in Bulgarian}

Формуляр за съгласие за проучване

В допълнение на моите отговорности като доброволец от Корпуса на Мира аз провеждам проучване относно употребата на билки като част изисквания за степен в Мичиганския Технологически Университет. Аз ще интервюирам хора през следващата година докато живея в Гърмен. Бих искала да ви попитам за събирането на билки в тази общност.

* Може да използвам това, което ще ми кажете в моя писмен доклад пред моите професори в университета. Когато пиша своя доклад за университета, аз няма да ви упомена в доклада, освен в снимките и това ще бъде само с ваше съгласие (вижте по-долу). Всичката събрана информация ще се съхранява в Мичиганския Технологически Университет.

* Няма никакви предвидими рискове включени в това проучване.

* Надявам се, че тази информация може да помогне за защита на районите, където билките в момента се събират.

* Ще върна финално копие от моето проучване в община Гърмен.

* Ще има някои специфични неща, за които бих искала да говоря, но вие може да ме питате въпроси и да казвате неща, които мислете, че трябва да зная, дори и аз да не питам. Не е задължително да разговаряте с мен или да отговаряте на моите въпроси. Може да решите да отговорите на някои от въпросите, но също може да решите, че има въпроси, на които не желаете да отговаряте. Дори сега да решите да отговаряте на въпросите, по-късно може да решите, че искате да спрете. Когато решите да спрете, аз ще спра да ви задавам въпроси. Вие решавате дали искате да ми казвате за източниците, които използвате в това общество. Нищо лошо няма да се случи нито на вас, нито на мен, ако решите да не отговаряте на въпросите от моето проучване.

* Мичиганският Технически Инстутационен Ревю Борд (Michigan Tech-IRB) ca прегледали моята молба за провеждане на този проект. Ако сте загрижени за вашите права в това проучване, моля свържете се с Ms. Joanne Polzien от MICHIGAN TECH-IRB на 906/487-2902 или имейл: jpolzien@mtu.edu.

* Въпросите относно проучването може да се отправят към Dr. Blair Orr на (906) 487-2291 или bdorr@mtu.edu

* Имате ли въпроси?

Съгласен съм да участвам в това проучване с разбирането, че няма да бъда упоменат и че аз мога да спра участието по всяко време.

Подпис:

Дата: 


\section{Формуляр за разрешение за фотографиране}

Бих искала да имам вашето разрешение да ви снимам. Разрешавате ли да използвам вашата снимка с вашето име в моя тезис или доклад?

Съгласен съм да използвате моята снимка с името ми.

Подпис: -------------------------------- Дата:

Подпис на изследователя: ------------------------- Дата: -------------------- 


\section{ВЫПРОСИ ЗА ИНТЕРВЮТО}

Село:

Етническа група:

Възраст:

Пол:

Брой души в семеството:

Професия:

Главен източник на доходи:

Вторични източници на доходи:

1. Какви недървесни горски ресурси събирате през годината?

А. По скала от 1 до 5 (с 5 най-важен) каква степен на важност бихте дали на тези недървесни горси ресурси?

- По какъв начин е важен всеки един от тях? (културно, като храна, лекарство, т.н.)

- Как се използва всеки един от тях специфично? (свеж, сушен, консервиран)

2. През кой месец събирате всеки един от тях?

3. Кой от тези недървесни горски ресурси е най-ценен парично?

4. Какви цени получавате на пазара за килограм от всяка билка?

А. Как се е променила цената през последните 20 години?

5. От всички тези недървесни горски ресурси кой е най-ценен в дома?

6. В какъв вид среда се среща всеки един от тези недървесни горски ресурси? (по хълмовете, близо до потоци, скалисти райони, т.н.)

7. Във всички тези среди ли ги събирате, или само в определени видове? Кои видове?

8. Специфични недървесни горски ресурси растат ли в същите среди? (Можете ли да разчитате да намерите два специфични горски ресурса да растат заедно?)

9. Специфичните недървесни горски ресурси на едно и също място ли се намират всяка година?

10 Специфичните недървесни горски ресурси по същото ли време се намират всяка година?

11. Какъв процент от твоя доход идва от събирането на недървесни горски ресурси?

А. Ако не продаваш билки, каква част от разходите ти замества това?

12. Колко килограма недървесни горски ресурси можеш да събереш всеки сезон?

А. Как се е променило това количество през последните 20 години?

Б. Ако количеството се е променило, защо мислиш, че се е променило?

13. Ако се налага да купиш билки от пазара, кои купуваш?

А. Как се е променило това през последните 20 години?

14. Намаляло ли е количеството на определени билки или се е увеличило през последните 20 години?

А. Ако е така, защо според теб, е станала тази промяна?

15. Променила ли се е средата, където обикновено си намирал своите билки, през последните 20 години?

А. Ако е така, защо мислиш, че средата се е променила? 
16. Правиш ли нещо да насърчаваш увеличаването на производството на недървесните горски ресурси, които събираш?

17. Специално за търсене на недървесни горски ресурси ли отиваш или това е продукт от други дейности в гората?

А. По принцип колко далече от дома отиваш, за да намериш недървесните горски ресурси?

18. Земята, от коята събираш, държавна ли е или частна?

19. Как отиваш до местата за събиране? (кола, пеша, с кон, магаре и каруца)

20 Сам ли събираш или с други хора? С кой?

21. Има ли конфликти относно събирането в някои райони? Опишете (място, групи от хора?) Нови ли са тези конфликти, или са от известно време? 